\title{
Measuring the cultural evolution of music: Cross-cultural and cross-genre case studies
}

\author{
Patrick E. Savage ${ }^{1,2,3}$
}

${ }^{1}$ Faculty of Environment and Information Studies, Keio University, Shonan Fujisawa Campus, Fujisawa, Japan

${ }^{2}$ School of Anthropology and Museum Archaeology, University of Oxford, United Kingdom

${ }^{3}$ Department of Musicology, Tokyo University of the Arts, Tokyo, Japan

Please note: This is a non-peer-reviewed preprint adapted from Chapter 4 of my $\mathrm{PhD}$ dissertation. I welcome questions, comments, citation, and constructive criticism, bearing in mind that this is a non-peer-reviewed draft subject to revision. Please direct correspondence to psavage@sfc.keio.ac.jp. Recommended citation: Savage, P. E., (2020). Measuring the cultural evolution of music: Cross-cultural and cross-genre case studies. PsyArXiV preprint. https://doi.org/10.31234/osf.io/mxrkw

In this article I apply methods for measuring the cultural evolution of music to four diverse case studies for which the history of musical evolution has already been qualitatively documented: 1) the divergence of the Scottish $17^{\text {th }}$ c. Lady Cassiles Lilt into nearly unrecognizable $2^{\text {th }}$ c. American descendants, 2) the merging of work songs from distant prefectures into the Japanese folk song Esashi Oiwake, 3) the simultaneous performance of vestigial, inaudible 1,000-year-old Chinese melodies and their radically changed descendants in the Japanese gagaku piece Seigaiha, and 4) the legal cases finding George Harrison's My Sweet Lord (1970) and Robin Thicke and Pharrell Williams' Blurred Lines 
(2013) liable for copyright infringement. Although the precise mechanisms differ and absolute rates of evolution vary almost 400 -fold within and between these case studies, several patterns are consistent with the predictions of previous research. These patterns include: 1) the relative ease of mutations to nearby pitches, 2) the relative predominance of insertions/deletions over substitutions, 3) the relative stability of functional notes (e.g., rhythmically stressed vs. unstressed), and 4) the relative stability of written over oral traditions. Both increases and decreases in complexity were observed, with no clear trend favouring one direction.

In previous research, I showed that the evolution of highly related British-American and Japanese folk song variants follows several general rules (Savage 2019; Savage et al. 2020). But do such rules apply to more complex examples from different cultures and genres? In this article, I will explore the generality of these proposed rules of melodic evolution using diverse case studies drawn from British-American and Japanese folk, art, and popular traditions. These case studies involve not simply highly related pairs with almost identical melodies, lyrics or instrumentation as in the previous analyses, but diverse melodies that have been adapted to completely different lyrics and/or instrumentation to the point where their connections to the original melodies are almost unrecognizable in some cases. After detailed descriptions of the mechanisms of each case study, I will quantitatively compare the patterns across the case studies to explore the degree to which trends are consistent across cultures/genres (these comparisons are summarized in Table 1.1).

\section{4-1. Case study 1 (Folk: British-American): Splitting of Lady Cassiles Lilt (1620) into Edward (1931) and The Bonnie House o' Airlie (1960)}

My first case study will be drawn directly from Bronson's (1959-72) corpus of Child ballads previously analyzed, but involving a more complex example than the highly related variants analyzed there. Throughout his compilation of 4,125 melodic variants 
for the 305 families of Child ballad texts, Bronson noted the appearance of several large tune families that encompassed many different texts. The largest of these was one he labeled the "Cassilis" family that was common in the US Appalachians, where it accompanied many unrelated texts (e.g., Child \#4 [Lady Isabel and the Elf Knight], \#13 [Edward; see Fig. 4.1], \#200 [Geordie], \#216 [Clyde's Water], and many more). However, the oldest documented appearance of this tune family was not in America, nor even accompanying a Child ballad text, but in a 1620 Scottish instrumental melody entitled Lady Cassiles Lilt (Fig. 4.1). 


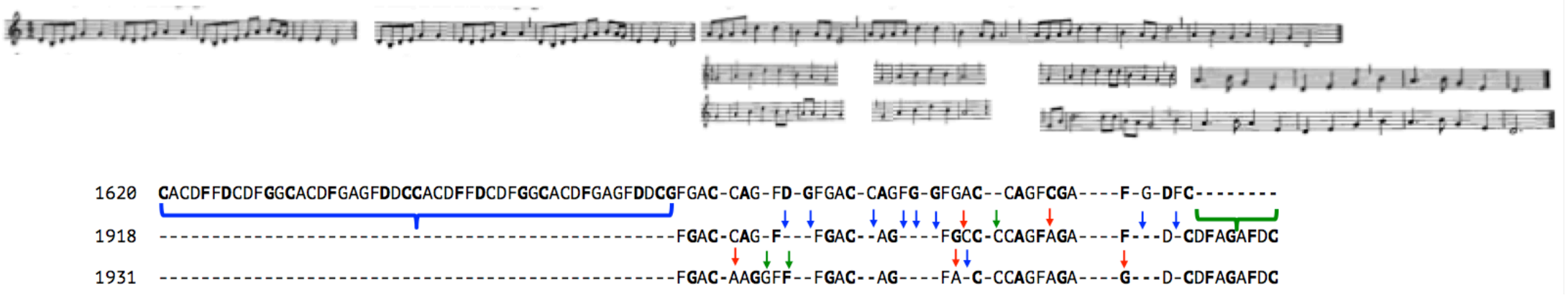

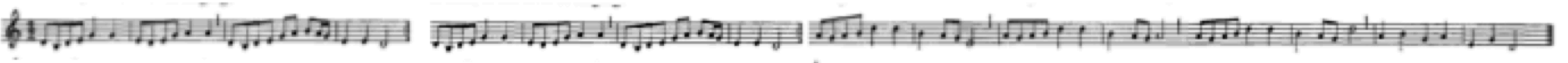

bx,

\section{Melodic evolution in British-American folk song pt. I (Lady Cassiles Lilt becomes Edward) \\ Figure 4.1 Melodic evolution in British-American folk song pt. I (Lady Cassiles Lilt becomes Edward) ${ }^{1}$}

The widespread Cassilis family variants are generally made up of four phrases that repeat for each stanza, like most English ballads. The Edward variants in Figure 4.1 are slightly different in being made up of five phrases, where the addition of the final fifth phrase is achieved by repeating both the melody and the text of the preceding fourth phrase. However, the original Lady Cassiles Lilt is a so-called "double strain" melody, in which the full 8-phrase melody is made up of two different four-phrase strains. Only the second of these strains gave rise to Bronson's Cassilis family, with the first strain being completely deleted between the 1620 Cassiles and its first documented appearance with the text of Edward in 1918.

1 The 1620 melody for Lady Cassiles Lilt is from the instrumental manuscript of John Skene in the National Library of Scotland (Bronson 1959-72: 201 [vol. III]). The 1918 melody for Edward (Child ballad no. 13) was recorded by Cecil Sharp from the singing of Mrs. Mary Gibson in North Carolina, USA (Bronson 1959-72: 241 [vol. I]). The 1931 melody (also for Edward) was recorded by Vance Rudolph from the singing of Mrs. Emma L. Dusenbury in Arkansas, USA (Bronson 1959-72: 242 [vol. I]). Cf. Ch. 2 for explanation of how musical notations (top) are coded as aligned sequences (bottom). 
There is at least one group of melodies, however, that retained parts of both the first and second strains of Lady Cassiles Lilt, (Fig. 4.2). Here, the entire 8-phrase tune was adapted to the text of The Bonnie House o' Airlie (Child \#199) in 1894, after which phrases 3-6 were deleted to create a 4-phrase version recorded in 1960.

Thus, over the course of three centuries of evolution, the melody of Cassiles diverged into at least two lineages so different that they retained only 6 of the original 85 notes in common ("CAGF", "D", and "C" from what were originally the $7^{\text {th }}$ and $8^{\text {th }}$ phrases). Yet it is possible to trace the sequence of insertions, deletions, and substitutions of each individual note and/or phrase that gave rise to these differences (Figs. 4.1 and 4.2).
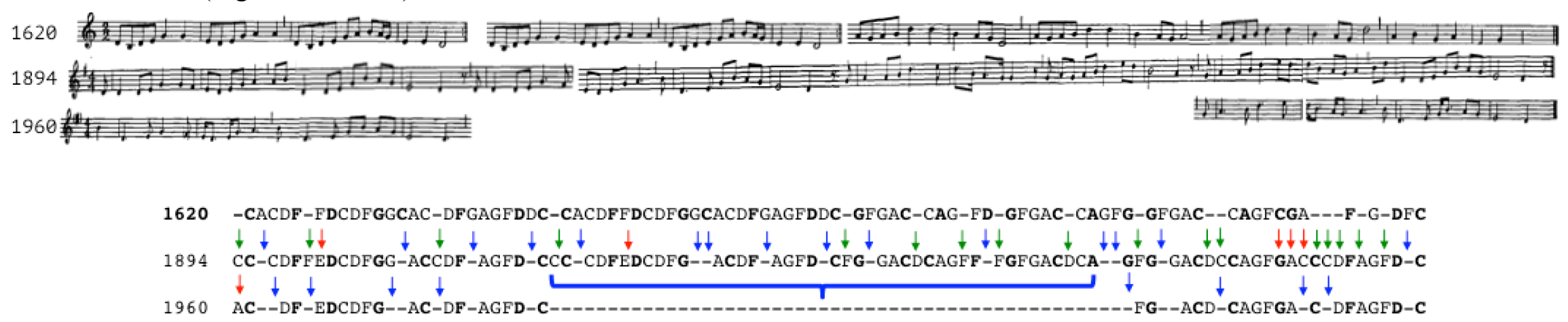

\section{Figure 4.2 Melodic evolution in British-American folk song pt. II (Lady Cassiles Lilt becomes The Bonnie House o' Airlie) ${ }^{2}$}

2 As in Fig. 4.1, the 1620 melody for "Lady Cassiles Lilt" is from the instrumental manuscript of John Skene in the National Library of Scotland (Bronson 1959-72: 201 [vol. III]). The 1894 melody for "The Bonnie House o' Airlie" was published by George Eyre-Todd in Ancient Scots Ballads (Bronson 1959-72: 196 [vol. III]). The 1960 melody for "The Bonnie House of Airlie" was sung by Scottish singer Isabel Sutherland and published by Selection Records Ltd. in New York, USA (Bronson 1959-72: 196 [vol. III]). 


\section{4-1-1. Simplification by phrase deletion}

In both cases, half of the original 8-phrase tune was deleted to condense a double-strain tune into a single-strain one. However, different halves were deleted in each case. In one case (Fig. 4.1), this major deletion was accompanied by the addition of a single phrase at the end by repetition of the previous phrase.

As a result, deletions strongly outnumbered insertions (124 to 27) over the course of Cassiles splitting into Edward and Airlie. This is consistent with a general trend for deletions to outnumber insertions found in Chapter 3, and contradicts general assumptions of a tendency for music to evolve from simple to complex. Insertions and deletions also greatly outnumbered substitutions (11), which is also consistent with the findings and mechanisms discussed in Chapters 2 and 3.

\section{4-1-2. Adaptation to new text by note insertion/deletion}

The adaptation of the melody to different texts is facilitated by the conventions of poetic meter. English ballads tend to be made up of four-line stanzas in which the first and third lines contain four stressed syllables and the second and fourth contain either three or four. Thus, a melody that fits the rhythmic stresses of one text can often be adapted with minor rhythmic alterations to fit another. For example, the first phrase of the second Cassiles strain contains four rhythmic stresses, which is the same number of stresses in the corresponding phrase of Edward ("What blood is that all on your shirt?") and Airlie ("The Duke o' Mont-rose has writ-ten to Ar-gyle").

However, the number of unstressed syllables and notes is more variable, and this requires more flexibility in inserting/deleting notes as necessary to accommodate different texts. For example, the Edward line above contains 8 syllables (four stressed, four unstressed), while the Airlie line contains 11 (four stressed, seven unstressed). Therefore, the corresponding Edward melodic phrase requires only 8 notes 
(FGACCAGF), while the Airlie melody requires 11 notes to accommodate the 11 syllables (FGGACDCAGFF). The original Cassiles instrumental phrase contained 10 notes (GFGACCAGFD), thus requiring a combination of both insertions and deletions of notes to accommodate the new texts (Figs. 4.1 and 4.2). Such interactions between melodies and lyrics represent a major functional mechanism of folk song evolution (Bronson 1969).

\section{4-1-3. Rhythmic stress and mutation rate}

The example of Cassiles evolving into Edward and Airlie is consistent with the findings in Chapter 3 that stressed notes are slightly more likely to mutate than stressed ones (the average unstressed to stressed mutation rate ratio of 1.9 is more than the neutral ratio of 1 if stress had no effect on mutation rate). However, this effect is not as strong as in the other Child ballad examples in Chapter 3, where stressed notes tended to be more than four times more resistant to change than unstressed ones.

I suspect two reasons for this weaker effect: 1) the massive deletions involved in the Cassiles example affect both stressed and unstressed notes equally, thus masking potential differences in the rest of the tunes. 2) The switch from instrumental tune to song text requires a change from a melody with accented downbeats to a song with iambic poetic meter (i.e., the first syllable tends to be weak followed by a strong second syllable). Thus, there is a contradiction between the strong instrumental downbeat and the weak song opening syllable. One way to resolve this is to delete the stressed opening note (as occurs in the Cassiles to Edward deletion discussed above), increasing the overall mutation rate for stressed notes.

\section{4-1-4. Melodic distance and mutation rate}

The role of melodic distance in this case study is consistent with the analyses of Chapter 3 in showing that almost all of the observed substitutions involve small 
melodic distances (mean substitution interval size $=2.5$ semitones). Ten out of the 11 substitutions were either 2nds (e.g., G to A) or 3rds (e.g., A to C), with the remaining substitution constituting a $4^{\text {th }}(\mathrm{C}$ to $\mathrm{G})$.

\section{4-1-5. Cassiles summary}

With some caveats, the general evolutionary principles developed in Chapters 2 and 3 apply to the splitting of the 1620 Scottish instrumental melody Lady Cassiles Lilt into the almost completely different variants of Edward and The Bonnie House o' Airlie sung in the USA in the $20^{\text {th }}$ century. The absolute and relative mutation rates observed in this process are quantified in the first two columns of Table 4.1.

I will now describe similar analyses of case studies of melodic evolution in different cultures/genres and compare the resulting rates and mechanisms (in the remaining columns of Table 4.1).

\section{4-2. Case study 2 (Folk: Japanese): Merging of Hirado Bushi and Komoro Magouta into Esashi Oiwake}

For my second case study, I will describe the evolution of the Japanese folksong Esashi Oiwake. I chose this example because: 1) it is often considered the most famous and most sophisticated Japanese folksong (it is sometimes called the "king of

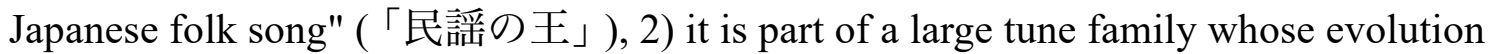
has already been qualitatively documented in detail (町田; 竹内; Hughes 2008: 108-118), and 3) because I have personal experience learning it and performing it at the annual national competition (Figs. 4.3). 


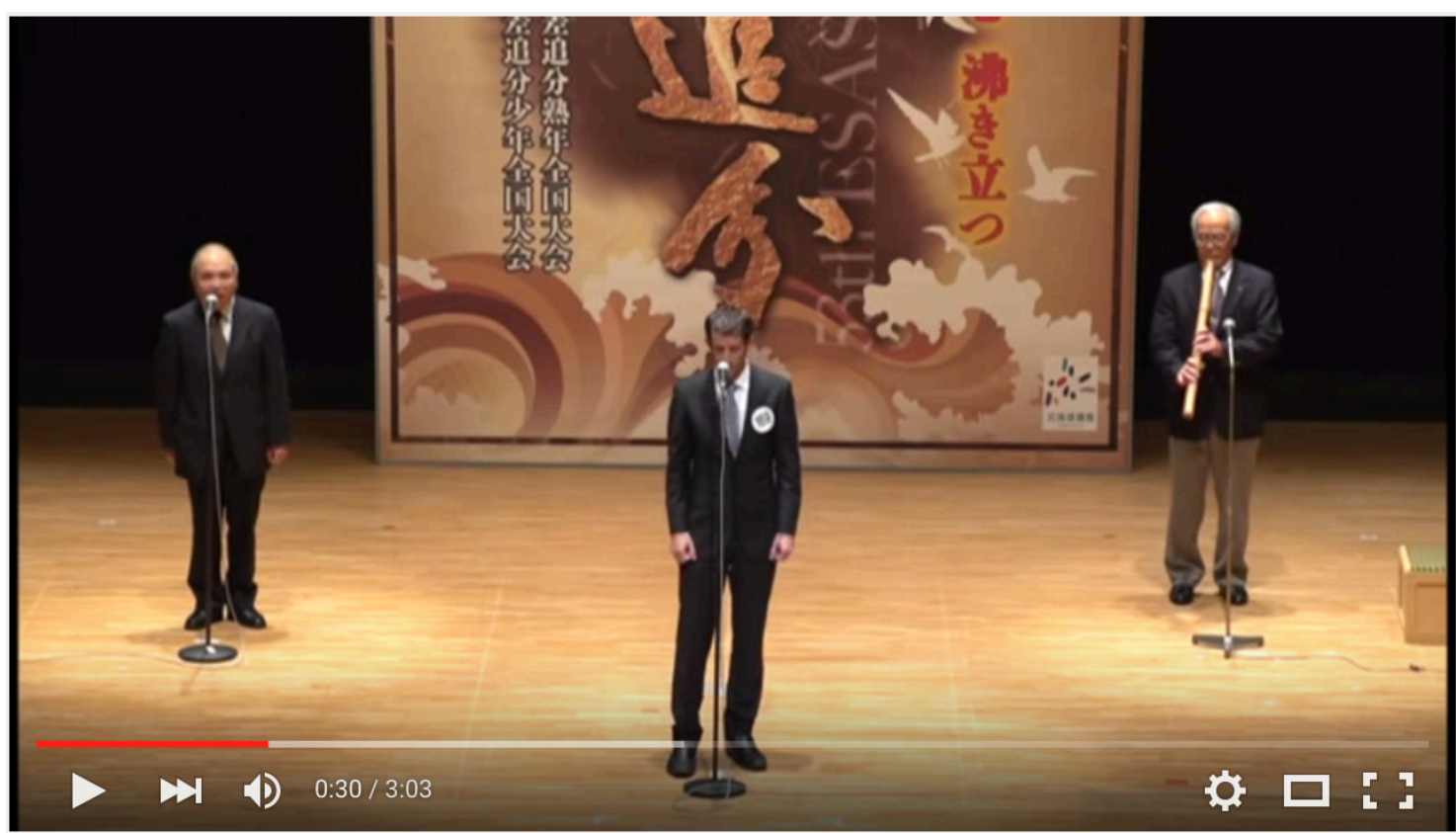

Figure 4.3 Me performing at the Esashi Oiwake national competition ${ }^{3}$

\section{4-2-1. Background}

In contrast to the example of Cassiles splitting into two songs discussed in the first case study, Esashi Oiwake evolved through a merging of two formerly independent melodies. One of these melodies had its origins as an unaccompanied, non-metric work song sung solo by pack-horse drivers (馬子) as they led their horses through the mountains of Shinano (now Nagano prefecture, central Japan). Komoro Magouta (小諸 馬子唄) represents a surviving melody thought to be close to this original style. This melody become gradually more elaborately ornamented and acquired shamisen

3 I (center) was one of several hundred performers who passed the regional qualifying competitions to be eligible to perform at the national competition held in Esashi, Hokkaido, during September 19-21, 2015. My teacher, Matsunaga Tatsuo (left) sang the unpitched interjections (ソイ掛け) between phrases, while Suetake Tadao (right) played the shakuhachi accompaniment. Unfortunately, I was not among the 50 singers to advance to the grand final the following day. Source:

https://youtu.be/3fu7GON1M8Q 
accompaniment as it was transmitted between a variety of singers including pack-horse drivers, prostitutes (飯盛女), and sailors to become the main melody (本唄) of Echigo Oiwake (Echigo is now Niigata prefecture, northeast Japan) and eventually also the main melody of Esashi Oiwake (the town of Esashi is on the northern-most Japanese island of Hokkaido).

The other melody that now appears as a prelude (前唄) and coda (後唄) before and after the main melody also originated as an unaccompanied work song, although in this case a metric one sung by groups of whalers in Kyushu (southwestern Japan). Hirado Bushi (平戸節) represents a surviving melody similar to this ancestral form. It followed a similarly convoluted route to Echigo, where it was added to the main melody of Echigo Oiwake as a coda（合の手）, since it was easier for audiences to sing along with than the more complicated main melody. Eventually, Esashi Oiwake came to include the coda not only after the main melody but also as a prelude (前唄). In a famous 1912 Tokyo concert, Hirano Genzaburo performed Esashi Oiwake accompanied by shakuhachi, which gradually came to supplant the shamisen as the usual preferred form of accompaniment. At some point during this process the metric rhythm of the original whaling song came to conform to the non-metric rhythm of the main melody, so that all parts of Esashi Oiwake are now sung without any clear beat (Koizumi Fumio (小泉 1984/2009) named his canonical non-metric type "Oiwake" after this song).

A simplified overview of the full evolution of Esashi Oiwake's melodic form is shown in Fig. 4.5. Detailed analysis of individual note changes are shown in Figs. 4.6 (prelude) and 4.7 (main melody).

In the course of its evolution, each phrase has tended to become longer and more ornamented, to the point where it approaches the physical limitations of the singer's breath capacity. Indeed, singers in competitions are automatically disqualified if they fail to sing the first 25 -second phrase in a single breath (a fate I narrowly avoided). 


\begin{tabular}{|lll|l|}
\cline { 2 - 4 } \multicolumn{1}{c|}{} & $\begin{array}{l}\text { Komoro } \\
\text { Magouta } \\
\text { ABCDECD }\end{array}$ & $\begin{array}{l}\text { Hirado } \\
\text { Bushi } \\
\text { abcde }\end{array}$ \\
\hline $\begin{array}{l}\text { Echigo } \\
\text { Oiwake }\end{array}$ & $\begin{array}{l}\text { ABCDECD } \\
\text { (main melody) }\end{array}$ & $\begin{array}{l}\text { abcde } \\
\text { (coda) }\end{array}$ \\
\hline $\begin{array}{l}\text { Esashi } \\
\text { Oiwake }\end{array}$ & (prelude) & $\begin{array}{l}\text { ABCDECD } \\
\text { (main melody) }\end{array}$ & $\begin{array}{l}\text { bc } \\
\text { (coda) }\end{array}$ \\
\hline
\end{tabular}

Figure 4.5 Melodic evolution in Japanese folk song pt. I (simplified overview of evolution of Esashi Oiwake melodic form) ${ }^{4}$

Ironically, the full song has now become too long for most performance contexts, with the entire combination of prelude, main melody, and coda taking approximately 8 minutes. Thus, most performances, including the national competition, focus only on the main melody, which takes approximately 2.5 minutes to sing, and is the only part of the song to have been formally codified into prescriptive notation. Performances of the full song with prelude and coda are generally reserved for special occasions, such as guest performances by previous champions.

After the collapse of the fish stock in Esashi at the end of the $19^{\text {th }}$ century, local leaders

4 Based on Machida and Takeuchi (町田 ; 竹内 1965). Here each letter represents a single phrase (not note), with lower case letters representing phrases originating from Hirado Bushi and capitals representing phrases originating from Komoro Magouta.

Detailed note-level alignments and mechanisms for these evolutions are shown in Fig. 4.6 (red) and Fig. 4.7 (blue), respectively. 
desperate to save their town from collapse turned to the famous folksong and decided to leverage its cultural capital into financial capital for the town (this process included the formal standardization in 1909 of the previously diverse melodies into a single notated "correct" (正調) main melody). So far, this effort has succeeded - the town of Esashi remains financially viable thanks in large part to the success of the Esashi Oiwake Association. The association is formally administered by the town's tourism department and attracts hundreds of singers (including myself) to the town for the annual competition and other events, managing to collect sizeable revenue from the registration fees and ranking examinations (analogous to the belt ranking systems in martial arts) as well as the general economic revenue provided by visiting tourists.

\section{4-2-2. Synchronic vs. diachronic comparison problems}

Unfortunately, unlike British-American folk song, Japanese folk song melodies were not documented before the $20^{\text {th }}$ century, severely limiting our ability to directly trace its evolution over several centuries in the diachronic manner shown above for Cassiles. In theory, it should be possible to reconstruct the "proto-melody" that gave rise to $20^{\text {th }}$ century melodic variants of the Oiwake tune family through careful synchronic comparison of large numbers of related members of this tune family (Boilès 1973). Ideally, this would also be combined with knowledge of general mechanisms of musical evolution (analogous to the comparative method used by historical linguists to reconstruct proto-languages; Campbell 2013) as well as advanced statistical techniques developed by evolutionary biologists for dealing with uncertainty in phylogenetic reconstruction (Bouckaert et al. 2014). As with linguistic/biological evolution, this would allow for a more rigorous and nuanced understanding of the factors governing musical change.

Unfortunately, such advanced phylogenetic reconstruction of musical tune families is too complicated to be practical within the constraints of this dissertation. Instead, I will rely for this case study on the simplifying assumptions of Machida and Takeuchi's 
analysis, which assumes that the ancestral forms of Esashi Oiwake can be best approximated by the simpler contemporary forms of the Oiwake family. This assumes a degree of evolutionary stasis, a concept that has been highly criticized (Stock 2006b). However, Machida and Takeuchi present a great deal of historical, musical, lyrical, and ethnographic evidence to suggest that in this case the assumption of stasis is at least partly justified: although other related variants have undoubtedly changed since the proto-Oiwake melodies, they appear to have changed less than has Esashi Oiwake. Thus, for the purposes of this case study, I will adopt the simplifying assumption that the evolution of Esashi Oiwake can be approximated as a linear sequence. In the future, the accuracy of this assumption should be checked using the more sophisticated evolutionary modeling techniques described above (this caveat also applies to a lesser degree to the other case studies discussed in this chapter).

\section{4-2-3. Rates and mechanisms}

In the previous case study of British-American folk song, the number of notes per phrase generally corresponded to the number of syllables, which varied depending on the lyrics. In contrast, Japanese folk song lyrics tend to have less variable numbers of syllables (usually 26 syllables organized into four lines of 7-7-7-5). However, the number of notes per phrase ends up being highly variable because there is a stronger tradition of using ornamental melisma (in which a single syllable is extended over many different notes), which can be easily inserted or deleted without affecting the lyrics. Among other things, this melisma makes it even easier to adapt the same tune to different lyrics in Japanese than in British-American folk songs. Indeed, all of the songs shown in Figs. 4.5-4.7 have completely different lyrics. In fact, even for the single song Esashi Oiwake, there are many completely different sets of lyrics that are considered acceptable, in contrast to the single rigidly prescribed melody. 


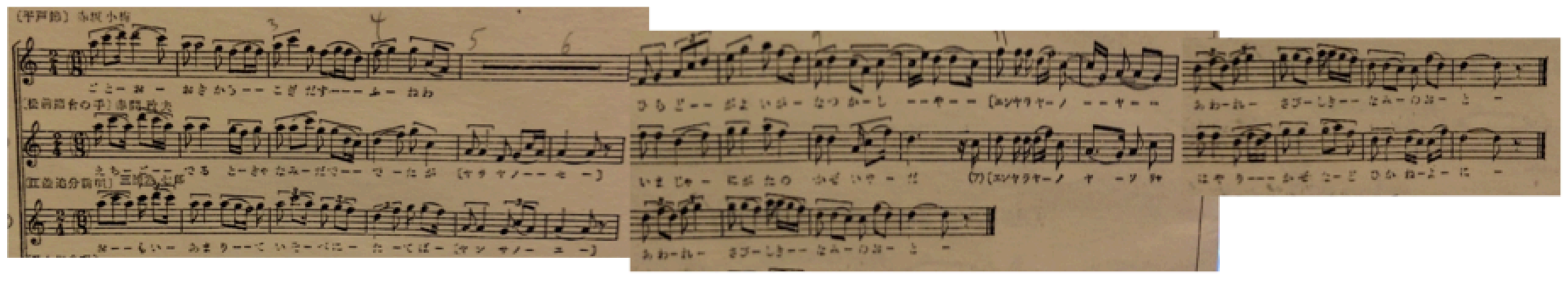

GbC-Cb-GG-FeFeG-b-FeFeCeFF bG-------eFGbCDF-G--eCbCbGbD-CbeeeCebFGF--eee-eCbFFFG-eCCbbbeCC

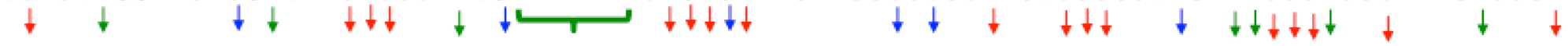
GbG-CbGGG-FeF-GGb-FFCbCeF-b-GGeFbGGeeCe-FF-G--eC-C-Gbe-CbCCCCeb-GFGbFFFFeCFFFFGFeCCCbbeCC

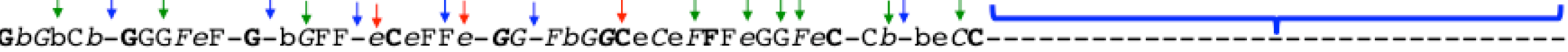

Figure 4.6 Melodic evolution in Japanese folk song pt. II (Hirado Bushi becomes Esashi Oiwake prelude) ${ }^{5}$

Figs. 4.5-4.7 show the processes of deletion, insertion, substitution, and merging of notes and phrases to form Esashi Oiwake. Two full phrases are deleted to form the prelude, but overall the number of notes lost through deletion is outnumbered by the number gained through the gradual accumulation of small ornamentation inserted in various places throughout the melody (117 insertions vs. 90

5 From Machida and Takeuchi (町田 ; 竹内 1965: 67). The top melody for Hirado Bushi is from Nagasaki prefecture, sung by Akasaka Koume. The middle melody for the Echigo Oiwake coda is from Niigata prefecture, sung by Akama Masao. The bottom melody for the Esashi Oiwake prelude is from Hokkaido prefecture, sung by Miura Tameshichiro. These versions were selected by Machida and Takeuchi to best show the melodic relationships within this tune family. 

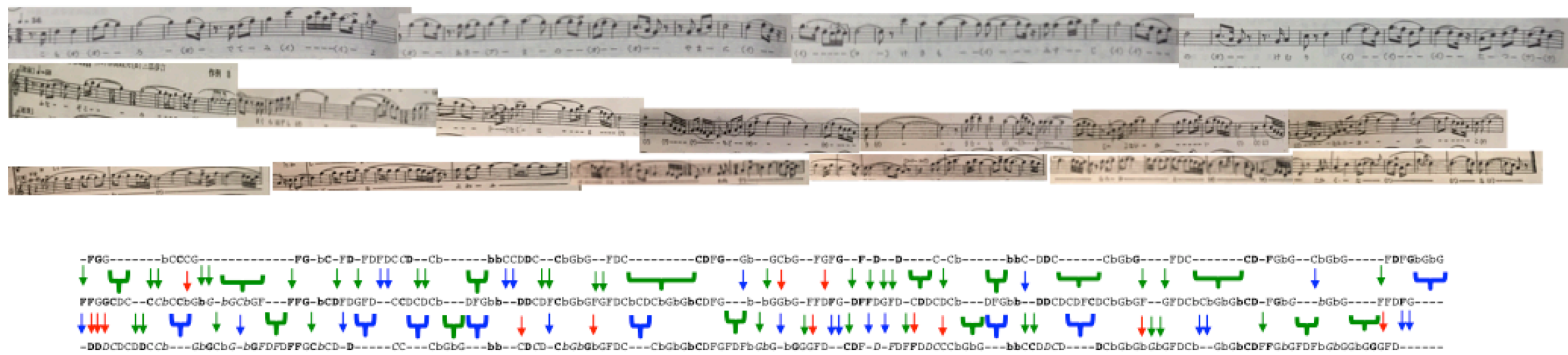

\section{Figure 4.7 Melodic evolution in Japanese folk song pt. III (Komoro Magouta becomes Esashi Oiwake main melody)}

deletions). These numbers would be even more strongly biased toward insertion if we include the extra four phrases added by the repetition of the $b c$ phrases at the end of the prelude and in the coda (see Fig. 4.5).

Substitutions (33) are again vastly outnumbered by both insertions and deletions. Although the substitutions observed here are slightly larger on average ( $\sim 4$ semitones, i.e., major 3 rds) than in the first case study of Cassiles ( $\sim 2.5$ semitones), they still represent relatively small intervals.

${ }^{6}$ From Machida and Takeuchi (町田 ; 竹内 1965: 63/66/68). The top melody for Komoro Magouta is from Nagano prefecture (singer unknown). The middle melody for the Echigo Oiwake main melody and the bottom melody for the Esashi Oiwake main melody are from the same performances as their corresponding coda/prelude shown in Fig. 4.6. 
As predicted, stressed notes were on average more resistant to change than unstressed ones. However, while this difference was strong in the main melody (unstressed : stressed ratio $=6.4)$, the difference was much smaller for the prelude (1.5). As with Cassiles, part of the explanation for this discrepancy probably lies in the fact that the major phrase deletions of the prelude serve to mask differences in the rest of the song. In addition, rhythmic stress assignments here are based on downbeats determined by the first note after a phrase-line (van Kranenburg, Volk, and Wiering 2013; Savage and Atkinson 2015), but in the case of Esashi Oiwake the transcription of the non-metric melody of Esashi Oiwake into a 2/4 meter seems dubious, and this metric ambiguity may also be serving to mask any effects of rhythmic stress.

\section{4-2-4. Esashi Oiwake summary}

Once again, the general evolutionary principles developed in Chapters 2 and 3 apply with some caveats to the evolution and merging of two stylistically and geographically distinct unaccompanied work songs into the famously long and complexly ornamented Esashi Oiwake. Unlike the previous British-American example in which Cassiles diverged into shorter, simpler tunes through deletion, Esashi Oiwake became longer and more complex over time through the merging of shorter tunes and the gradual accumulation of inserted ornamentation, to the point where its length became limited by physical constraints on breathing.

\section{4-3. Case study 3 (Art: Japanese gagaku): Vestigial 1,000-year-old Chinese melodies in modern Seigaiha}

Although cultural evolutionary theory is particularly useful for tune family evolution in folk musics, it can also be useful for classical and popular musics. For example, Heather Windram and colleagues have recently applied phylogenetic methods to reconstructing the evolutionary divergence of a single Western classical music composition, Orlando Gibbons' Prelude in G (1613) into a set of variant notations over 
the course of approximately one century of hand-copying (Windram, Charlston, and Howe 2014). One interesting finding of their analysis was the coexistence of both "silent" and "audible" mutations, and the ways in which silent mutations can pave the way for audible ones, analogous to "silent" and "functional" genetic mutations. For example, in Fig. 4.8, versions 1 (left) and 2 (right) sound different, but the top and bottom variants of version 1 sound identical despite differences in the way the rhythms are notated.

Ex.1 Gibbons, Prelude in G, variants in bar 20, left hand

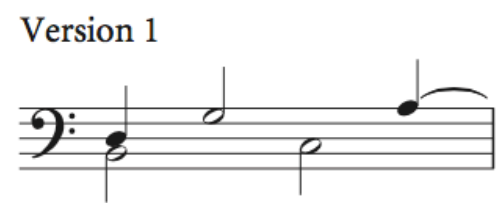

\section{Parthenia}

Lcm 2093 (no tie)

Och Mus. 89

NYp Drexel 5612

B Ms. Ly A2

Lbl Add. 23623(i)

Lbl Add. 23623(ii)

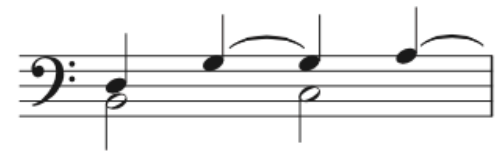

Lbl Add. 31403

Pc Rés 1186 bis I (tie in

$T$ voice from previous bar)
Version 2

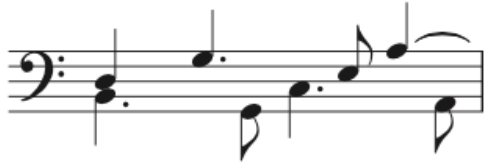

Och Mus. 47

Cfm Mu Ms 653

HAdolmetsch II e.17

Tn MS N-3/35 (tie replaced

by dot of addition at start of next bar)

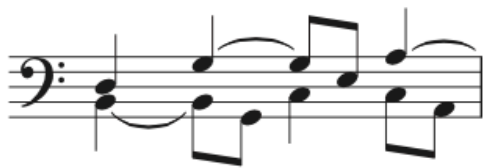

Lbl Add. 22099 (split at

half bar over two systems)

Figure 4.8 "Silent" and "audible" mutations in Gibbons' Prelude in G $^{7}$

7 From Windram et al. (2014: 524). Versions 1 (left) and 2 (right) sound different, with Version 2 having three audible insertions of eighth notes. However, the top and bottom variants of Version 1 sound identical despite the "silent" mutation where a half note becomes notated as two tied quarter notes. Such silent mutations can eventually results in functional consequences (e.g., failing to copy the tie results in the appearance of a new note). 
In this case study, I want to explore a more extreme form of evolution of notated classical music in a non-Western genre: Japanese gagaku (雅楽), which is often described as "the world's oldest continually performed orchestral music" (S. G. Nelson 2008: 36). Specifically, I will build on Alan Marett's (1985) analysis of $\sim 1,000$ years of documented changes in the notation of the piece Seigaiha (青海波) from the oldest togaku (唐楽) repertoire. There are some methodological issues involved in interpreting gagaku notation and performance practice that have resulted in some controversy around the conclusions of Marett and Laurence Picken's school of gagaku scholars with whom he is associated (Marett 1985; S. G. Nelson 2008; Hughes 2010). Of particular relevance to this dissertation, the degree to which the older notations represent full descriptive notations of the melody as opposed to a skeleton notation to which unwritten, orally transmitted melodic aspects were added is unclear. However, for the purposes of this short case study I will simply accept Marett's transcriptions and analysis in order to explore whether his analysis can be usefully expanded and compared with the other case studies in this chapter through the use of evolutionary sequence alignment techniques.

\section{4-3-1. Background}

Gagaku is a ritual court music that is the oldest documented Japanese music (S. G. Nelson 2008). Some gagaku music accompanies song or dance, while some is purely instrumental. The instrumentation has changed over the years, but the core ensemble has generally included winds (e.g., ryuteki [flute], hichiriki [reed pipe], sho [mouth organ]), strings (e.g., biwa [lute], koto [zither]), and percussion (e.g., taiko [drum], shoko [gong]). All the non-percussion instruments play more or less the same melody in heterophony, although as we shall see this same melody has become wildly different in different instruments.

The oldest gagaku repertoire is the togaku repertoire, which was imported from the Chinese Tang dynasty during the $7^{\text {th }}-9^{\text {th }}$ centuries. Although this repertoire later died 
out in China, it has continued in Japan all the way to the present day, albeit with major changes (including those introduced through a revival following a virtual extinction during the $15^{\text {th }}-16^{\text {th }}$ century wars that destroyed the Japanese imperial court). One of the most striking changes is the fact that, although the core notes of the earliest melodies remain detectable in modern notation, they are now almost completely inaudible. There are at least three reasons for this: 1) The melodies have been best preserved in the lowest notes of the aitake chords played by the sho mouth organ (only the lowest notes are explicitly notated - the aitake have developed in a parallel oral tradition), which are perceptually masked by the higher notes in the chords and by the more melodic-sounding flute and hichiriki. 2) The melodies preserved in the more prominent flute and hichiriki have accumulated so many additional notes in between the original ones that there is little resemblance remaining. 3) The tempo of gagaku appears to have slowed dramatically by at least a factor of four, such that the notes are now so far apart and the former melodies so long that they violate psychological principles of perceptual grouping. Instead, what used to be brief ornamental additions have now slowed down enough to be perceived as a true melody, while the former melody remains with little or no melodic function, analogous to a vestigial organ or limb (e.g., human appendix, wings in flightless birds). This phenomenon has striking parallels to the development of European motets from a slowed down Gregorian chant cantus firmus (Hughes 2010).

This phenomenon has been demonstrated by Marett (1985) for the evolution of the piece Seigaiha. By transcribing notations from the $10^{\text {th }}$ to $20^{\text {th }}$ centuries for the flute, mouth organ, and other instruments into standard Western staff notation and aligning them (Figs. 4.9 and 4.10), Marett showed that the bottom note of the modern sho part was "virtually identical" (Marett 1985: 416) to ancient flute versions, while the relationship of the modern and ancient flute parts was "not immediately discernible" (Marett 1985: 420). Analyzing Marett's alignments using the quantitative methods developed in Chapter 2 allows us to investigate these statements more precisely. 


\section{4-3-2. Rates and mechanisms}

The creation of the 29 -note $20^{\text {th }}$ c. sho lower-note melody from the 26 -note $10^{\text {th }} \mathrm{c}$. flute part involved only six note changes $(4$ insertions [green arrow], 1 deletion [blue], 1 substitution [red]), retaining a melodic identity of $87 \%$ through a mutation rate of 0.0002 per site per year (Fig. 4.9 and Table 4.1). During the same time period, the flute part more than tripled in length by accumulating a staggering 63 insertions and 3 substitutions, retaining a melodic identity of only $40 \%$ through a mutation rate of 0.0025 per site per year - a rate more than ten times faster than the rate observed for the sho from the same shared ancestral melody in the same 1,000-year period (Fig. 4.10 and Table 4.1).

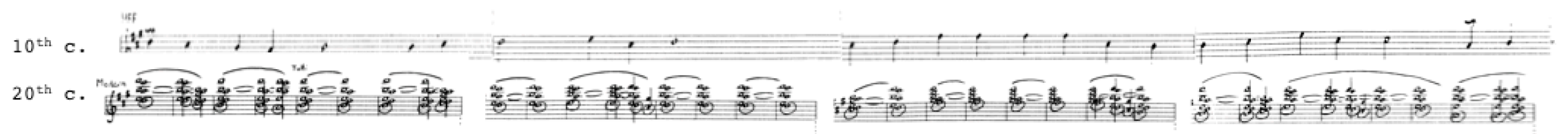

\section{$10^{\text {th }} \mathbf{C} \cdot \mathbf{e D C b C C D e F - D e - D e G G G G - D C C D F - D D b C}$ $20^{\text {th }}$ C. eDCbCCDeFédeéDeG-GGéDCCDFédébC}

Figure 4.9 Melodic evolution in Japanese gagaku pt. I (modern sho part from Seigaiha) ${ }^{8}$

\footnotetext{
8 From Marett (1985: 412/423). The $10^{\text {th }}$ c. flute is from Hakuga no fue-fu (HFF; compiled by Minamoto no Hiromasa), while the $20^{\text {th }}$ c. sho (mouth organ) is from 芝 (1969).
} 


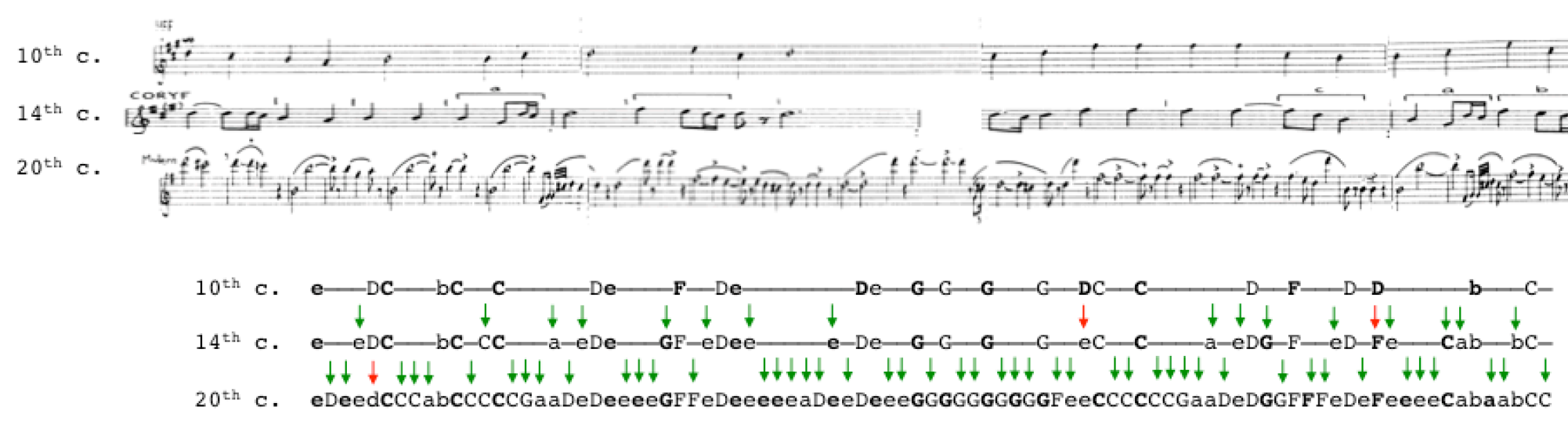

Figure 4.10 Melodic evolution in Japanese gagaku pt. II (modern flute part from Seigaiha) ${ }^{9}$

The average melodic distance of the four substitutions observed in Figs. 4.9 and 4.10 is 1.5 semitones (i.e., in between a minor and major $2^{\text {nd }}$ ). Of these four substitutions, three (one D to d; two D to e) represent the smallest possible melodic distance of one semitone, while the fourth (D to F) represents a slightly larger but still relatively small minor $3^{\text {rd }}$. D is the only note to undergo substitution in this example, consistent with some historical variability in the intonation of this scale degree in gagaku (Terauchi 2011). However, not all Ds are substituted, unlike some of the modal shifts observed in British-American folk song in Chapter 3, where all of the third scale degree changed from minor to major or vice-versa.

9 From Marett (1985: 423-424). As in Fig. 1, the $10^{\text {th }}$ c. version is from HFF, while the $20^{\text {th }}$ c. version is from 芝 (1969). The 14th c. version is from Chū Ōga ryūteki yōroku-fu (CORYF, written by Yamanoi no Kagemitsu; also known as Ōga Kagemitsu no ryūteki yōroku-fu; cf. 遠藤 1996). 
As predicted, rhythmically stressed sites were on average more resistant to change than unstressed ones (unstressed : stressed ratio $=15$ ). Interestingly, in this case this rhythmic stress effect did not seem to apply to substitutions (three of the four substitutions occurred on stressed notes). Instead, the higher rate of unstressed notes was driven by the fact that the predominant evolutionary mechanism was the addition of unstressed ornamental notes (although over time some of these notes eventually became stressed as the metric structure accommodated the slowing melody; Marett 1985; S. G. Nelson 2008; Hughes 2010).

\section{4-3-3. Seigaiha summary}

The general principles of melodic distance and rhythmic stress developed above also apply to the divergent evolution of the modern sho and flute melodies of the Japanese gagaku piece Seigaiha from their common ancestral flute melody notated 1,000 years earlier. During the same 1,000-year period, the original melody evolved at vastly different rates in these two instruments, such that there is little similarity remaining in the two resulting melodies even though they continue to be performed simultaneously. The original flute melody remains largely unchanged as a vestigial, unheard structure at the bottom of the sho chords, while the modern flute melody more than tripled its original length by accumulating ornamentation and slowing down to the extent that this ornamentation came to function as a new melody in its own right.

\section{4-4. Case study 4 (Popular: Contemporary Western) Subconscious plagiarism in George Harrison's My Sweet Lord}

In both popular and classical musics, there is often artistic and legal pressure to be original. Composers thus often try to avoid directly copying entire melodies from previous work, even if they borrow uncopyrightable aspects such as smaller melodic motives or stylistic features (e.g., chord changes, instrumentation, rhythmic patterns). Thus, in many cases the techniques for studying melodic evolution developed here 
may be more applicable to classical and popular musics using local sequence alignment algorithms to identify evolution/borrowing of individual motives (Urbano et al. 2011; Smith; and Waterman 1981) rather than entire melodies.

However, there are still many applications for studying global evolution of entire melodies, including cover song identification and plagiarism detection (Robine et al. 2007; Müllensiefen and Pendzich 2009). In this case study, I want to show how the method I have developed for measuring musical evolution can be usefully applied to one of the most famous plagiarism cases: the US\$1.6 million judgement that the Beatles' George Harrison was liable for subconcious plagiarism of the Chiffons' 1962 hit He's So Fine when composing his 1970 hit My Sweet Lord (Judge Owen 1976). Although researchers in the field of music information retrieval (MIR) have developed a number of techniques for automatically identifying potential musical plagiarism (some of which have been applied to the My Sweet Lord example, e.g., Robine et al. 2007; Müllensiefen and Pendzich 2009), my approach adds the unique benefit of evaluating whether observed melodic similarities are significantly higher than might be expected for stylistically similar works.

\section{4-4-1. Background}

Musical copyright law is highly complex, but it essentially recognizes the lyrics and melodies of the written score as the copyrightable essence of a musical composition, excluding stylistic and performance features such as chords, instrumentation, vocal timbre, and small ornamental/microrhythmic variation in the recorded performance (Cronin 2015; Fruehwald 1992). For My Sweet Lord, there was no question of lyrical plagiarism, as the lyrics were completely different from He's So Fine. Instead, the melodies sounded similar enough that the crucial question of the copyright case was whether this degree of similarity was due to illegal copying or simply by chance due to the similar motives and scale structures common to the style of much popular music at the time. 
George Harrison admitted to having heard He's So Fine (as most people would have, since it was a number one hit on the pop charts), but claimed to have composed $M y$ Sweet Lord without consciously drawing on it. The judge accepted Harrison's story, but maintained that the two songs were nevertheless so similar as to be "virtually identical except for one phrase" (Judge Owen 1976: 180). The judge went on to conclude even more strongly:

"it is clear that My Sweet Lord is the very same song as He's So Fine with different words, and Harrison had access to He's So Fine. This is, under the law, infringement of copyright, and is no less so even though subconsciously accomplished." (Judge Owen 1976: 180-181)

\section{4-4-2. Melodic similarity}

Using my methods, it is possible to quantify the melodic similarity beyond the vague "virtually identical" into the more precise percent melodic identity developed in Chapter 2. As one of the most famous cases, it will be particularly informative to know the percent melodic identity of these two tunes as a benchmark for comparing the many similar copyright cases ${ }^{10}$.

Fig. 4.11 shows my own melodic alignment of He's So Fine and My Sweet Lord. This analysis confirms that there are indeed statistically significant similarities between the two. They share a melodic identity of $54 \%\left(I D=28, \mathrm{~L}_{1}=59, \mathrm{~L}_{2}=44\right)$ that is extremely unlikely to be due to chance resemblances given the types of scales and lengths of the tunes $(p<.00001)$.

10 Cronin (2016) has an excellent overview of many high-profile examples (involving Led Zeppelin's Stairway to Heaven, Duke Ellington's Satin Doll, John Williams' soundtrack to E.T., Rogers \& Hammerstein's There Is Nothing Like A Dame, Justin Bieber's Somebody to Love, The Black Eyed Peas' Boom Boom Pow, etc.). 
On the other hand, 54\% seems a far cry from the judge's conclusion that they are "virtually identical" or "the same song with different words". In fact, there have been a total of 43 note changes, including two entire phrase deletions and nearly one whole phrase insertion, as well as over a dozen independent insertions, deletion, or substitutions comprising only one or two notes (Fig. 4.11).

1962
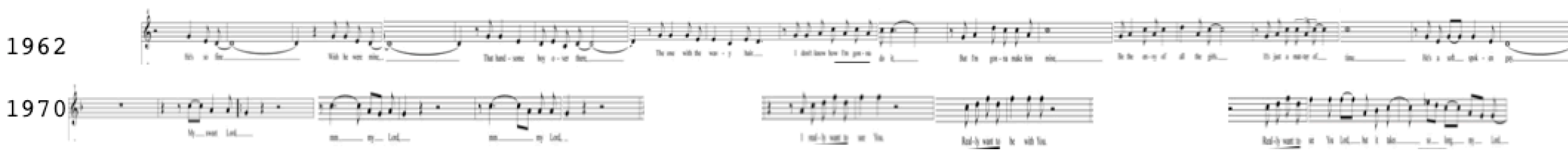

1962

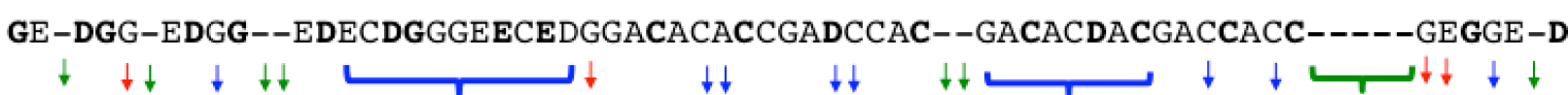

1970

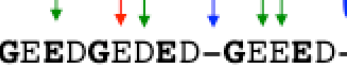

$\downarrow \downarrow$

Figure 4.11 Melodic evolution in popular music (subconscious plagiarism of He's So Fine by My Sweet Lord) ${ }^{11}$

\section{4-4-3. Rates and mechanisms}

Although the judge claims that these changes simply represent the melody being "modified to suit the words" (Judge Owen 1976: 178), such modification clearly cannot account for the extent of the changes. Indeed, even though the opening lines "He's so fine"

11 Based on Judge Owen (1976). Melodies for the Chiffons' He's So Fine and George Harrison's My Sweet Lord are both taken from http://mcir.usc.edu/cases/1970-1979/Pages/brightharrisongs.html. 
and "My sweet lord" share the same number of syllables (three) with similar stress patterns, Harrison inserts an appoggiatura to lengthen the corresponding melody to four notes (GEED), while the three syllables of "He's so fine" are accommodated with only three notes (GED).

As in the previous case studies, note deletions (27) and insertions (12) vastly outnumber substitutions (4). As with the British-American folk songs analyzed in Ch. 3, there is a tendency toward simplification through deletion, but this is accompanied by a lesser degree of insertion. Interestingly, while Harrison's melody is simpler in terms of the number of notes, it is more complicated in various other dimensions, such as the use of ornamentation (e.g., the appoggiatura shown above) and more thickly textured chords.

The average melodic distance of the four substitutions observed in Fig. 4.11 is 3.5 semitones (i.e., in between a major and minor $3^{\text {rd }}$ ). Three of these four substitutions represent a substitution of a $\mathrm{G}$ by a minor $3^{\text {rd }}$ above (b) or below (E), while the final substitution represents a substitution of an E by a perfect $4^{\text {th }}$ above (A). While these are somewhat larger than the intervals observed in other case studies (e.g., 1.5 semitone average for Seigaiha), $3{ }^{\text {rd }}$ s still represent relatively small intervals.

As predicted, rhythmically stressed sites were on average more resistant to change than unstressed ones (unstressed : stressed ratio $=6.1$ ). This suggests that rhythmic stress plays a role in musical evolution even when this evolution is happening subconsciously. (Stress in this case study is assigned based on syllable stress, rather than downbeats, both since syllable information is available and because the heavy syncopation of both parts makes this a more appropriate measure of rhythmic stress.)

\section{4-4-4. My Sweet Lord summary}

The general principles of melodic distance and rhythmic stress developed above in 
cases of conscious copying and evolution of folk and classical melodies also apply to subconscious copying found in a high-profile copyright case in popular music. The techniques I have developed have shown promise both in adding quantitative precision to vague statements about melodic similarity (i.e., My Sweet Lord and He's So Fine being "the same song with different words") and in confirming that observed similarities $(54 \%)$ are significantly greater than expected by chance for stylistically similar songs $(P<.00001)$. Such techniques could well have important applications in other ongoing or future copyright disputes, as would a better understanding of the nuances and mechanisms of musical evolution in different cultures and genres.

\section{4-4-5. Appendix: No significant melodic similarity between Blurred Lines and Got to Give It Up}

As an example of the reverse case - where evolutionary analysis may help disprove claims of copyright infringement - I want to briefly present an analysis of a high-profile copyright case currently under appeal: Blurred Lines.

In 2015, a jury award Marvin Gaye's heirs US\$7.4 million for its finding that Robin Thicke and Pharrell Williams' massive hit Blurred Lines (2013) was guilty of plagiarizing Marvin Gaye's Got To Give It Up (1977) ${ }^{12}$. One of the primary pieces of evidence was testimony by musicologist Judith Finell who, when asked whether she thought that Thicke and Williams copied Got To Give It Up, replied "Yes...musically there's no other explanation for so many similarities"13. The jury's decision is currently under appeal on the grounds that they were allowed to consider similarities in extra-melodic information such as instrumentation (e.g., shared use of cowbell) and

\footnotetext{
12 http://mcir.usc.edu/inplay/Pages/williams.html

13 http://mcir.usc.edu/inplay/Pages/documents/williamsfinelldepo.pdf, p.48. Here Finell is referring to a "constellation of 8 similarities" (p.57) that includes aspects like instrumentation, timing, and vocal style as well as melody.
} 
vocal timbre (e.g., shared use of falsetto) rather than strictly melodic similarities contained in the musical notation.

It is difficult for me to manually apply my new melodic sequence alignment techniques as I have done in the above case studies because Finell's testimony does not appear to provide any melodic alignments of the type shown here, nor provide enough information to construct such alignments. Furthermore, there is not enough melodic similarity between the two songs that I can identify to confidently create such an alignment myself. This is where the automated algorithms introduced in Chapter 2 are useful for their objective power.

Fig. 4.12 shows the melodies of the first two verses of each song and their coding as unaligned melodic sequences using the standard technique developed in Chapter 2 (including transposing them to the same tonic). Applying the automated melodic sequence alignment algorithm from Chapter 2 to align these sequences gives a value of $19 \%$ melodic identity ${ }^{14}$. By comparing this against a baseline distribution of melodic similarity generated by randomly reordering these sequences shows us that the observed degree of $19 \%$ melodic identity is not statistically significant $(P=.49)$, and is easily found in any two random melodies of these lengths that use these scales (stylistic features such as scale choice and melody length are not copyrightable).

${ }_{14}$ Note that this value of $19 \%$ melodic identity is also almost certainly an overestimate of the true melodic identity, since automatic alignment ignores rhythmic and other structural information and thus tries to maximize similarity even when that results in finding melodic matches that are musically implausible. For comparison, automated alignment of He's So Fine and My Sweet Lord returned a value of 60\% melodic identity rather than the true value of $54 \%$ found above through manual alignment. 


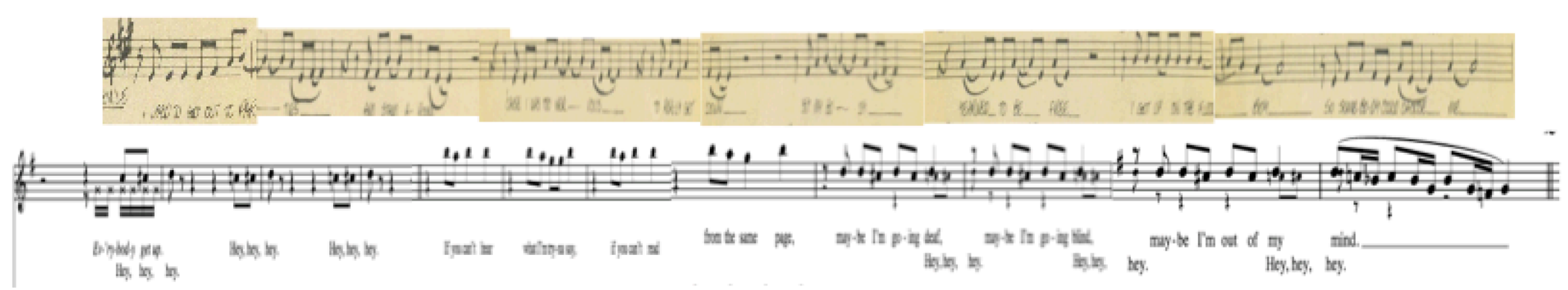

1977 GGGGACDCGAADAAGGGACDCGAACACAGACDCGACGGCGCGDDDDDDEDCGACAGCGC

2013 FgGFgGFgGEDEEEDCCEEDEEEDCEGGgGgGGGgGgGGGgGgGGFeFeCeCbC

Figure 4.12 Unaligned melodic sequences for Got To Give It Up and Blurred Lines ${ }^{15}$

This analysis provides quantitative support to the claims of the defendants and independent experts alike that the jury's initial verdict was "unfounded, illogical, and a miscarriage of justice"16. However, a more comprehensive analysis would ideally be based on the plausibility of a manual melodic alignment of official notation for both songs provided by Finell or another musicologist who believes they can make a case for significant melodic similarities between the two songs. It is also conceivable that a more nuanced

15 The first two verses for each song are shown transcribed into melodic sequences in a common tonic using the method described in Chapter 2. The melody for Got To Give It Up (1970) is taken from the copyright registration listed at http://mcir.usc.edu/inplay/Pages/williams.html. The melody for Blurred Lines (2013) was taken from http://www.musicnotes.com/sheetmusic/mtd.asp?ppn=MN0118109, as no full notation could be found in court documents.

Automatic alignment of these tunes gives a non-significant value of $19 \%$ melodic identity $(P=.49)$.

16 http://mcir.usc.edu/inplay/Pages/williams.html 
melodic analysis that includes rhythmic as well as pitch information may reveal evidence for significant melodic similarities, although I find this unlikely for this particular case.

\section{4-5. General comparison across case studies}

The rates and types of mutations for each case study analyzed above are compared in Table 4.1 below. Comparison among and within case studies gives an indication of the degree of variability in different evolutionary parameters. All averages mentioned below are weighted means across these columns from Table 4.1.

\section{4-5-1. Absolute mutation rates highly variable}

The overall average musical mutation rate in these case studies is 0.02 per site per year. However, average absolute mutation rates vary almost 400 -fold from the slowest-evolving (Seigaiha sho part) to the fastest (My Sweet Lord). Indeed, even within the same piece, different lineages and different instruments can vary greatly (e.g., mutation rates for the sho and flute parts of Seigaiha differ by over 10-fold).

It is not possible to calculate absolute mutation rates for Esashi Oiwake because of the lack of pre- $20^{\text {th }}$ century documented recordings (musical "fossils") with which to calibrate the time dimension. However, it seems likely that the common ancestor of these melodies diverged during the Edo period (1603-1868), during which many Japanese folk songs are thought to have emerged (Hughes 2008). This would give an estimated rate of approximately 0.004 to 0.02 per site per year, which falls towards the middle of the distribution of other mutation rate values given in the table.

This rate variability is consistent with findings that rates of linguistic change vary greatly within and between families, such that there is no single universal "glottoclock" that can be used to independently date language divergence (Campbell 2013; Atkinson 
Table 4.1 Comparison of evolutionary parameters within and between case studies ${ }^{17}$

\begin{tabular}{|c|c|c|c|c|c|c|c|}
\hline & $\begin{array}{l}\text { Cassiles } \\
\text { to } \\
\text { Edward }\end{array}$ & $\begin{array}{l}\text { Cassiles } \\
\text { to } \\
\text { Airlie }\end{array}$ & $\begin{array}{l}\text { Oiwake } \\
\text { (prelude) }\end{array}$ & $\begin{array}{l}\text { Oiwake } \\
\text { (main } \\
\text { melody) }\end{array}$ & $\begin{array}{l}\text { Seigaiha } \\
(\text { sho })\end{array}$ & $\begin{array}{l}\text { Seigaiha } \\
\text { (flute) }\end{array}$ & $\begin{array}{l}\text { My } \\
\text { Sweet } \\
\text { Lord }\end{array}$ \\
\hline Time (years) & 411 & 440 & $?$ & $?$ & 1000 & 1000 & 8 \\
\hline Initial melody & & & & & & & \\
\hline length (notes) & 85 & 85 & 69 & 90 & 26 & 26 & 59 \\
\hline Mutations & 74 & 86 & 87 & 143 & 6 & 66 & 43 \\
\hline $\begin{array}{l}\text { Average mutation } \\
\text { rate (per note per } \\
\text { year) }\end{array}$ & 0.0021 & 0.0023 & $?$ & $?$ & 0.0002 & 0.0025 & 0.0911 \\
\hline Insertions & 11 & 17 & 23 & 94 & 4 & 63 & 12 \\
\hline Deletions & 58 & 63 & 44 & 46 & 1 & 0 & 27 \\
\hline Substitutions & 5 & 6 & 20 & 13 & 1 & 3 & 4 \\
\hline $\begin{array}{l}\text { Indel vs. } \\
\text { substitution ratio }\end{array}$ & 13.8 & 13.3 & 3.4 & 10.8 & 5.0 & 21.0 & 9.8 \\
\hline $\begin{array}{l}\text { Mean substitution } \\
\text { size (semitones) }\end{array}$ & 2.6 & 2.5 & 3.9 & 4.46 & 1.0 & 1.7 & 3.5 \\
\hline $\begin{array}{l}\text { Unstressed vs. } \\
\text { stressed mutation } \\
\text { rate ratio }\end{array}$ & 1.6 & 2.1 & 1.5 & 6.4 & 6.8 & 23.8 & 6.1 \\
\hline
\end{tabular}

and Gray 2005). It is also consistent with an emerging consensus from evolutionary biology that even the so-called "molecular clock" used to calculate genetic divergence is also actually much more variable than previously believed (Ho and Larson 2006).

17 Question marks signify that absolute mutation rates could not be calculated for Esashi Oiwake because of the lack of pre- $20^{\text {th }}$ c. notation. See text for details. 


\section{4-5-2. Bias toward small substitutions}

Overall, note substitutions were strongly biased towards small mutational distances. The average mutational distance of substitutions was 2.8 semitones (i.e., a minor $3^{\text {rd }}$ ) across all case studies, and was less than 5 semitones (i.e., a perfect $4^{\text {th }}$ ) in each case study. In each case, the average size was lower than the tritone (6 semitones) that would be predicted if note substitutions were random and not influenced by mutational distance. Instead, this bias toward small intervals is consistent with my earlier predictions in Chapter 3 that smaller intervals are more likely to be substituted and to be passed down to future generations because such changes are more easily produced and less easily perceived as being different. Such biases also have parallels in linguistics and biology, where sound changes to phonetically similar sounds are most likely (Campbell 2013) and amino acids are most likely to mutate to ones requiring only a single nucleotide change (Dayhoff, Schwartz, and Orcutt 1978).

\section{4-5-3. Stressed notes more stable than unstressed}

On average, stressed notes were approximately 7 times more resistant to change than unstressed notes were. This trend was consistent for all examples, although the differences were less pronounced for the folk songs containing major deletions of entire phrases (i.e., Cassiles to Edward and the Esashi Oiwake prelude). Presumably, this is largely because deletions of entire phrases affected stressed and unstressed notes equally, masking any differences (see the case studies above for further discussion).

This stress bias is consistent with purifying selection against functional change also observed in linguistics and biology. Although these case studies are not large enough to make a quantitative comparison of ornamental or final note stability as done in Chapter 3 , they seem to tentatively conform to the same patterns. For example, the final note was unchanged in all but one example (Esashi Oiwake main melody), and most of the numerous insertions in the Japanese folk and gagaku examples were originally 
ornamental (although these ornamental notes gradually came to assume more functional roles over time).

\section{4-5-4. Predominance of insertion/deletion over substitution}

The average ratio of indels (insertions/deletions) to substitutions was approximately 11 to 1 . This strong preference for indels was consistent across all examples, and was also consistent with the findings of Chapter 3. This bias toward indels is strikingly opposite to the situation in biology, where substitutions vastly outnumber indels. As explained in Chapter 3, this is likely explained by the flexible rhythms of music that allow rhythms to be modified to accommodate insertion/deletion of ornamentation without disrupting the meter, in contrast to the fixed 3-nucleotide DNA codons that cause "frame shifts" of any genetic indels that don't encompass multiples of 3 nucleotides.

\section{4-5-5. No clear trend toward complexification or simplification}

The simplest method of measuring a trend toward complexity or simplification is to count whether the number of notes in the melody increases (via insertion) or decreases (via deletion). These case studies gave no indication of any general trend in either direction. Deletions outnumbered insertions in four out of the seven columns in Table 4.1, while the opposite was true for the remaining three. Even within one individual song, Esashi Oiwake, the prelude became simplified through deletion of two entire ending phrases, while the main melody became more complex through the accumulation of many small ornamental insertions throughout the melody. This suggests that, if there is any general trend toward complexity or simplification, it is much more nuanced and context-dependent than the strong general trends identified above involving melodic distance and rhythmic stress.

\section{4-5-6. Possible role of transmission fidelity}


It is difficult to compare the different types of transmission fidelity in these case studies in the manner done in Chapter 3 with oral vs. written transmission. However, the large variation in absolute mutation rates among cases studies is consistent with differences in transmission fidelity. Specifically, the remarkable fidelity with which $87 \%$ melodic identity was maintained over 1,000 years in the sho part of Seigaiha with a mutation rate of .0002 per site per year seems very likely to be aided by its preservation in written notation. The faster - but still relatively slow - rates of the British-American folk song seem to fit with a combination of oral and written transmission suggested by its history of documentation, and the slightly faster rate suggested by the Japanese folk song example is consistent with that repertoire being transmitted almost entirely orally until the introduction of limited written notation and audio recordings in the $20^{\text {th }}$ century. Finally, the extremely high rate of evolution in $M y$ Sweet Lord is consistent with the idea that the transmission fidelity in this example was so low that its composer was not even consciously aware that he was copying a pre-existing work at all.

On the other hand, the fact that different instruments within the same gagaku piece displayed wildly different mutation rates suggests that written notation alone does not guarantee low mutation rates. Interestingly, gagaku is currently taught through a combination of written and oral transmission, but the nature of earlier transmission systems remains controversial (S. G. Nelson 2008). In gagaku and other genres, a thorough understanding of the evolution of the transmission systems may help to better understand the evolution of the melodies themselves.

\section{4-6. Conclusion}

Through these four case studies spanning melodic evolution in folk, classical, and popular traditions of Western and non-Western music, I have quantitatively explored the generality of the evolutionary mechanisms predicted and identified in highly related British-American Child ballads in Chapter 3. Using a series of complex and 
diverse examples, I showed that the same principles of melodic distance, rhythmic function and transmission fidelity operated consistently in almost all case studies, while there was little evidence of any consistent trends in absolute mutation rate or directional evolution. In the future, more detailed quantitative analyses of large, comprehensive samples will be needed to confirm the suggestions of these limited case studies.

\section{ACKNOWLEDGMENTS}

I thank M. Atsushi, H. de Ferranti, A. Tsukahara, and Y. Uemura for comments on my $\mathrm{PhD}$ dissertation (Savage , 2017), from which this article is adapted.

Funding: This research was supported by Grant-in-Aid \#19KK0064 from the Japan Society for the Promotion of Science, a Japanese Ministry of Education, Culture, Sports, Science and Technology (MEXT) scholarship, and startup grants from Keio University (Keio Global Research Institute, Keio Research Institute at SFC, and Keio Gijuku Academic Development Fund).

\section{References}

\section{【Japanese】}

遠藤徹 1996 「大神流笛譜考」『日本音楽史研究』第 1 巻、48〜 68 ページ 金城厚 1990 「歌詞音列法による追分節の比較」『民族音楽』第 5 巻 1 号、30 〜36ページ 小泉文夫 1984/2009『合本一一日本伝統音楽の研究』小島美子; 小柴はるみ編、 東京 : 音楽之友社

サベジ、パトリック 2014 「音楽と遺伝子からみた日本列島への民族移動—— アイヌ音楽を中心に一一」修士論文、東京芸術大学

芝祐泰 編 1969 『五線譜による雅楽総譜』東京：カワイ楽譜 
町田佳声 ; 竹内勉 編 1965 『江差追分と佐渡おけさ-—民謡源流考』川崎：

コロンビア AL-5047/50（4つの LP）

NHK （日本放送協会）編 1994-1994 『日本民謡大観』東京：NHK（13 巻）

【Non-Japanese】

Adler, Guido. 1885/1981. "The Scope, Method, and Aim of Musicology." Translated by Erica Mugglestone. Yearbook for Traditional Music 13: 1-21.

Atkinson, Quentin D. 2011. "Phonemic Diversity Supports a Serial Founder Effect Model of Language Expansion from Africa.” Science 332: 346-49.

Atkinson, Quentin D., and Russell D. Gray. 2005. "Curious Parallels and Curious Connections: Phylogenetic Thinking in Biology and Historical Linguistics." Systematic Biology.

Baer, Charles F., Michael M. Miyamoto, and Dee R. Denver. 2007. "Mutation Rate Variation in Multicellular Eukaryotes: Causes and Consequences." Nature Reviews Genetics 8 (8): 619-31.

Bartlett, Frederic C. 1932. Remembering: A Study in Experimental and Social Psychology. Cambridge: Cambridge University Press.

Bartók, Béla. 1931. Hungarian Folk Music. London: Oxford University Press.

Bayard, Samuel P. 1950. "Prolegomena to a Study of the Principal Melodic Families of British-American Folk Song.” Journal of American Folklore 63 (247): 1-44.

- 1954. "Two Representative Tune Families of British Tradition." Midwest Folklore 4 (1): 13-33.

Bentley, R. Alexander, Carl P. Lipo, Harold A. Herzog, and Matthew W. Hahn. 2007. "Regular Rates of Popular Culture Change Reflect Random Copying." Evolution and Human Behavior 28 (3): 151-58.

Blackmore, Susan J. 1999. The Meme Machine. New York: Oxford University Press.

Boilès, Charles L. 1973. "Reconstruction of Proto-Melody." Anuario Interamericano de Investigacion Musical 9: 45-63.

Bor, Joep. 1975. "Raga, Species and Evolution." Sangeet Natak: Journal of the 
Sangeet Natak Akademi 35: 17-48.

Bouckaert, Remco, Joseph Heled, Denise Kühnert, Tim Vaughan, Chieh Hsi Wu, Dong

Xie, Marc A. Suchard, Andrew Rambaut, and Alexei J. Drummond. 2014.

"BEAST 2: A Software Platform for Bayesian Evolutionary Analysis." PLoS Computational Biology 10 (4): 1-6.

Bouckaert, Remco, Philippe Lemey, Michael Dunn, Simon J. Greenhill, Alexander V. Alekseyenko, Alexei J. Drummond, Russell D. Gray, Marc A. Suchard, and Quentin D. Atkinson. 2012. "Mapping the Origins and Expansion of the Indo-European Language Family.” Science 337 (6097): 957-60.

Boyd, Robert, and Peter J. Richerson. 1985. Culture and the Evolutionary Process. Chicago: University of Chicago Press.

Broadwood, Lucy E . 1904. "Songs from Various Sources." Journal of the Folk-Song Society 1 (5): 264-67.

Brewer, J., M. Gelfand, J. C. Jackson, I. F. MacDonald, P. N. Peregrine, P. J. Richerson, P. Turchin, H. Whitehouse, and D. S. Wilson. 2017. "Grand Challenges for the Study of Cultural Evolution." Nature Ecology and Evolution 1 (70): 1-3. doi:10.1038/s41559-017-0070.

Bronson, Bertrand H. 1959-72. The Traditional Tunes of the Child Ballads: With Their Texts, according to the Extant Records of Great Britain and America [4 Volumes]. Princeton, NJ: Princeton University Press.

-1969. The Ballad as Song. Berkeley: University of California Press.

- 1976. The Singing Tradition of Child's Popular Ballads. Princeton: Princeton University Press.

Brown, Steven, and Joseph Jordania. 2013. "Universals in the World's Musics." Psychology of Music 41 (2): 229-48.

Brown, Steven, Patrick E. Savage, Albert Min-Shan Ko, Mark Stoneking, Ying-Chin Ko, Jun-Hun Loo, and Jean A. Trejaut. 2014. "Correlations in the Population Structure of Music, Genes and Language." Proceedings of the Royal Society B: Biological Sciences 281: 20132072.

Callaway, Ewen. 2007. "Music Is in Our Genes." Nature News. 
doi:10.1038/news.2007.359.

Campbell, Lyle. 2013. Historical Linguistics: An Introduction. 3rd ed. Edinburgh:

Edinburgh University Press.

Carneiro, Robert L. 2003. Evolutionism in Cultural Anthropology: A Critical History.

Boulder, CO: Westview Press.

Cavalli-Sforza, L. Luca, and Marcus W. Feldman. 1981. Cultural Transmission and

Evolution: A Quantitative Approach. Princeton: Princeton University Press.

Child, Francis James. 1882-98/1904. The English and Scottish Popular Ballads [5

Volumes]. Edited by Helen Child Sargent and George Lyman Kittredge. Boston:

Houghton, Mifflin and Co.

Claidière, Nicolas, Simon Kirby, and Dan Sperber. 2012. "Effect of Psychological Bias

Separates Cultural from Biological Evolution." Proceedings of the National Academy of Sciences 109 (51): E3526.

Clarke, David. 2014. “On Not Losing Heart: A Response to Savage and Brown's 'Toward a New Comparative Musicology."' Analytical Approaches to World Music 3 (2): 1-14.

Collard, Mark, Stephen J. Shennan, and Jamshid J. Tehrani. 2006. "Branching versus Blending in Macroscale Cultural Evolution: A Comparative Study.” In Mapping Our Ancestors: Phylogenetic Methods in Anthropology and Prehistory, edited by Carl P. Lipo, Michael J. O’Brien, Stephen J. Shennan, and Mark Collard, 53-63. Hawthorne, NY: Aldine de Gruyter.

Cowdery, James R. 1984. "A Fresh Look at the Concept of Tune Family." Ethnomusicology 28 (3): 495-504.

Cronin, Charles. 2015. "I Hear America Suing: Music Copyright Infringement in the Era of Electronic Sound." Hastings Law Journal 66 (5): 1187-1254.

—. 2016. "Music Copyright Infringement Resource.” http://mcir.usc.edu/.

Currie, Thomas E., Simon J. Greenhill, Russell D. Gray, Toshikazu Hasegawa, and Ruth Mace. 2010. "Rise and Fall of Political Complexity in Island South-East Asia and the Pacific." Nature 467 (7317): 801-4.

Currie, Thomas E., and Ruth Mace. 2011. "Mode and Tempo in the Evolution of 
Socio-Political Organization: Reconciling 'Darwinian' and 'Spencerian' Evolutionary Approaches in Anthropology." Philosophical Transactions of the Royal Society B: Biological Sciences 366: 1108-17.

—. 2014. "Evolution of Cultural Traits Occurs at Similar Relative Rates in Different World Regions." Proceedings of the Royal Society B: Biological Sciences 281 (1795): 20141622.

Danchin, Etienne, Anne Charmantier, Frances A. Champagne, Alex Mesoudi, Benoit Pujol, and Simon Blanchet. 2011. "Beyond DNA: Integrating Inclusive Inheritance into an Extended Theory of Evolution." Nature Reviews Genetics 12: $475-86$.

Darwin, Charles. 1859/2009. The Origin of Species by Means of Natural Selection. 6th ed. Cambridge: Cambridge University Press.

- 1871. The Descent of Man, and Selection in Relation to Sex. London: John Murray.

Dawkins, Richard. 1976. The Selfish Gene. Oxford: Oxford University Press.

Dayhoff, M. O., R. M. Schwartz, and B.C. Orcutt. 1978. "A Model of Evolutionary Change in Proteins." In Atlas of Protein Sequence and Structure, 345-52.

Deutsch, Diana, ed. 2013. The Psychology of Music. 3rd ed. London: Academic Press/Elsevier.

Doolittle, R. F. 1981. "Similar Amino Acid Sequences: Chance or Common Ancestry?" Science 214 (4517): 149-59.

Doolittle, W. Ford. 1999. "Phylogenetic Classification and the Universal Tree." Science 284 (5423): 2124-28.

Duffy, Siobain, Laura A. Shackelton, and Edward C. Holmes. 2008. "Rates of Evolutionary Change in Viruses: Patterns and Determinants." Nature Reviews Genetics 9 (4): 267-76.

Dunn, Michael, Simon J. Greenhill, Stephen C. Levinson, and Russell D. Gray. 2011. "Evolved Structure of Language Shows Lineage-Specific Trends in Word-Order Universals." Nature 473 (7345): 79-82.

Ellis, Blair K., Heungsun Hwang, Patrick E. Savage, Bing-Yi Pan, Annabel J. Cohen, 
and Steven Brown. 2016. "Identifying Style-Types in a Sample of Musical Improvisations Using Dimensional Reduction and Cluster Analysis.” Psychology of Aesthetics, Creativity, and the Arts. doi:10.1037/aca0000072.

Erickson, Edwin E. 1976. "Tradition and Evolution in Song Style: A Reanalysis of Cantometric Data." Cross-Cultural Research 11 (4): 277-308.

Fogarty, Laurel, Nicole Creanza, and Marcus W. Feldman. 2015. "Cultural Evolutionary Perspectives on Creativity and Human Innovation." Trends in Ecology \& Evolution 30 (12): 736-754.

Fracchia, Joseph, and Richard C. Lewontin. 1999. "Does Culture Evolve?" History and Theory 8: 52-78.

Fruehwald, E. Scott. 1992. "Copyright Infringement of Musical Compositions: A Systematic Approach.” Akron Law Review 26 (1): 15-44.

Fuentes, Agustin, and Polly Wiessner. 2016. "Reintegrating Anthropology: From Inside Out - An Introduction to Supplement 13.” Current Anthropology 57 (S13): S3-12. Gavryushkina, Alexandra, David Welch, Tanja Stadler, and Alexei Drummond. 2014. "Bayesian Inference of Sampled Ancestor Trees for Epidemiology and Fossil Calibration.” PLoS Computational Biology 10 (12): e1003919.

Gould, Stephen J. 1989. Wonderful Life: The Burgess Shale and the Nature of History. New York: Norton.

Graça da Silva, Sara, and Jamshid J. Tehrani. 2016. "Comparative Phylogenetic Analyses Uncover the Ancient Roots of Indo-European Folktales.” Royal Society Open Science 3 (1): 150645.

Grant, Catherine. 2014. "Music Endangerment: How Language Maintenance Can Help.” New York: Oxford University Press.

Grauer, Victor A. 2006. "Echoes of Our Forgotten Ancestors." The World of Music 48 (2): $5-58$.

- 2011. Sounding the Depths: Tradition and the Voices of History. CreateSpace: http://soundingthedepths.blogspot.com/.

Gray, Russell D., and Quentin D. Atkinson. 2003. "Language-Tree Divergence Times Support the Anatolian Theory of Indo-European Origin.” Nature 426 (6965): 435- 
39.

Gray, Russell D., David Bryant, and Simon J. Greenhill. 2010. "On the Shape and Fabric of Human History." Philosophical Transactions of the Royal Society B: Biological Sciences 365: 3923-33.

Gray, Russell D., Alexei J. Drummond, and Simon J. Greenhill. 2009. "Language Phylogenies Reveal Expansion Pulses and Pauses in Pacific Settlement." Science 323 (5913): 479-83.

Hammarström, Harald. 2016. "Linguistic Diversity and Language Evolution.” Journal of Language Evolution 1 (1): 19-29.

Ho, Simon Y. W., and Greger Larson. 2006. "Molecular Clocks: When Times Are a-Changin'." Trends in Genetics 22 (2): 79-83.

Hofstadter, Richard. 1955. Social Darwinism in American Thought. Boston: Beacon Press.

Honing, Henkjan, Carel ten Cate, Isabelle Peretz, and Sandra E. Trehub, eds. 2015. "Biology, Cognition and Origins of Musicality [Special Issue]." Philosophical Transactions of the Royal Society B: Biological Sciences 370 (1664).

Howard, Keith, ed. 2012. Music as Intangible Cultural Heritage: Policy, Ideology, and Practice in the Preservation of East Asian Traditions. Farnham, Surrey, UK: Ashgate.

Howe, Christopher J., and Heather F. Windram. 2011. "Phylomemetics: Evolutionary Analysis beyond the Gene.” PLoS Biology 9 (5): e1001069.

Hruschka, Daniel J, Simon Branford, Eric D Smith, Jon Wilkins, Andrew Meade, Mark Pagel, and Tanmoy Bhattacharya. 2015. "Detecting Regular Sound Changes in Linguistics as Events of Concerted Evolution.” Current Biology 25 (1): 1-9.

Hughes, David W. 2008. Traditional Folk Song in Modern Japan: Sources, Sentiment and Society. Kent: Global Oriental.

- 2010. "The Picken School and East Asia: China, Japan and Korea." Ethnomusicology Forum 19 (2): 231-39.

Huron, David. 2006. Sweet Anticipation: Music and the Psychology of Expectation. Cambridge: MIT Press. 
International Folk Music Council. 1955. "Resolutions: Definition of Folk Music." Journal of the International Folk Music Council 7: 23.

Jan, Steven. 2007. The Memetics of Music: A Neo-Darwinian View of Musical Structure and Culture. Hants: Ashgate.

Judge Owen. 1976. Bright Tunes Music v. Harrisongs Music 420 F. Supp. 177 (S.D.N.Y. 1976). Vol. 177.

Kartomi, M. 2001. "The Classification of Musical Instruments: Changing Trends in Research from the Late Nineteenth Century, with Special Reference to the 1990s." Ethnomusicology 45 (2): 283-314.

Kirby, Simon, Hannah Cornish, and Kenny Smith. 2008. "Cumulative Cultural Evolution in the Laboratory: An Experimental Approach to the Origins of Structure in Human Language.” Proceedings of the National Academy of Sciences of the United States of America 105 (31): 10681-86.

Kloss, Jurgen. 2012. ““... Tell Her To Make Me A Cambric Shirt': From the 'Elfin Knight' to 'Scarborough Fair.'” http://www.justanothertune.com/html/cambricshirt.html.

Labov, William. 1994-2010. Principles of Linguistic Change [3 Volumes]. Oxford: Blackwell.

Laland, Kevin N., and Gillian R. Brown. 2011. Sense and Nonsense. 2nd ed. New York: Oxford University Press.

Lawson, Francesca R. Sborgi. 2012. “Consilience Revisited.” Ethnomusicology 56 (1): $86-111$.

Le Bomin, Sylvie, Guillaume Lecointre, and Evelyne Heyer. 2016. "The Evolution of Musical Diversity: The Key Role of Vertical Transmission." PLoS ONE 11 (3): e0151570.

Leroi, Armand M, Robert M MacCallum, Matthias Mauch, and Austin Burt. 2012. "Reply to Claidière et A1.: Role of Psychological Bias in Evolution Depends on the Kind of Culture." Proceedings of the National Academy of Sciences of the United States of America 109 (51): E3527.

Leroi, Armand M., Matthias Mauch, Patrick E. Savage, Emmanouil Benetos, Juan 
Bello, Maria Panteli, Joren Six, and Tillman Weyde. 2015. "The Deep History of Music Project." In Proceedings of the Folk Music Analysis 2015 Workshop, 8384.

Leroi, Armand M., and Jonathan Swire. 2006. "The Recovery of the Past." The World of Music 48 (3): 43-54.

Levinson, Stephen C., and Russell D. Gray. 2012. "Tools from Evolutionary Biology Shed New Light on the Diversification of Languages." Trends in Cognitive Sciences 16 (3): 167-73.

Lewontin, R. C. 1970. "The Units of Selection." Annual Review of Ecology and Systematics 1 (7): 1-18.

Lieberman, Erez, Jean-Baptiste Michel, Joe Jackson, Tina Tang, and Martin A. Nowak. 2007. "Quantifying the Evolutionary Dynamics of Language.” Nature 449 (7163): 713-16.

Liu, Di, Weifeng Shi, Yi Shi, Dayan Wang, Haixia Xiao, Wei Li, Yuhai Bi, et al. 2013. "Origin and Diversity of Novel Avian Influenza A H7N9 Viruses Causing Human Infection: Phylogenetic, Structural, and Coalescent Analyses.” The Lancet 381 (9881): 1926-32.

Lomax, Alan, ed. 1968. Folk Song Style and Culture. Washington, DC: American Association for the Advancement of Science. 1977. "Appeal for Cultural Equity.” Journal of Communication. - 1980. "Factors of Musical Style." In Theory \& Practice: Essays Presented to Gene Weltfish, edited by Stanley Diamond, 29-58. The Hague: Mouton. 1989. "Cantometrics." International Encyclopedia of Communications.

Lomax, Alan, and Norman Berkowitz. 1972. "The Evolutionary Taxonomy of Culture." Science 177 (4045): 228-39.

MacCallum, Robert M., Matthias Mauch, Austin Burt, and Armand M. Leroi. 2012. "Evolution of Music by Public Choice." Proceedings of the National Academy of Sciences of the United States of America 109 (30): 12081-86.

Mace, Ruth, and Clare J. Holden. 2005. "A Phylogenetic Approach to Cultural Evolution." Trends in Ecology and Evolution 20 (3): 116-21. 
Maranda, Elli Kongas. 1970. "Deep Significance and Surface Significance: Is Cantometrics Possible?" Semiotica 2 (2): 173-84.

Marett, Allan. 1985. "Togaku: Where Have the Tang Melodies Gone, and Where Have the New Melodies Come From?” Ethnomusicology 29 (3): 409-31.

Marris, Emma. 2008. “The Language Barrier.” Nature 453: 446-48.

Mauch, Matthias, Robert M. MacCallum, Mark Levy, and Armand M. Leroi. 2015. “The Evolution of Popular Music: USA 1960-2010." Royal Society Open Science $2(5): 150081$.

May, Alex C. W. 2004. "Percent Sequence Identity: The Need to Be Explicit." Structure 12 (May): 737-38.

McShea, Daniel W., and Robert N. Brandon. 2010. Biology's First Law: The Tendency for Diversity and Complexity to Increase in Evolutionary Systems. Chicago: University of Chicago Press.

Merriam, Alan P. 1964. The Anthropology of Music. Evanston: Northwestern University Press.

Mesoudi, Alex. 2011. Cultural Evolution: How Darwinian Theory Can Explain Human Culture and Synthesize the Social Sciences. Chicago: University of Chicago Press. Mesoudi, Alex, and Andrew Whiten. 2008. "The Multiple Roles of Cultural Transmission Experiments in Understanding Human Cultural Evolution." Philosophical Transactions of the Royal Society B: Biological Sciences 363 (1509): 3489-3501.

Mesoudi, Alex, Andrew Whiten, and Kevin N. Laland. 2006. "Towards a Unified Science of Cultural Evolution." The Behavioral and Brain Sciences 29 (4): 32983.

Mongeau, Marcel, and David Sankoff. 1990. "Comparison of Musical Sequences." Computers and the Humanities 24: 161-75.

Müllensiefen, Daniel, and Marc Pendzich. 2009. "Court Decisions on Music Plagiarism and the Predictive Value of Similarity Algorithms." Musicae Scientiae 13 (1 Suppl): 257-95.

Mundy, Rachel. 2006. "Musical Evolution and the Making of Hierarchy." The World of 
Music 48 (3): 13-27.

Needleman, Saul B., and Christian D. Wunsch. 1970. "A General Method Applicable to the Search for Similarities in the Amino Acid Sequence of Two Proteins." Journal of Molecular Biology 48: 443-53.

Nei, Masatoshi, Yoshiyuki Suzuki, and Masafumi Nozawa. 2010. “The Neutral Theory of Molecular Evolution in the Genomic Era." Annual Review of Genomics and Human Genetics 11 (1): 265-89.

Nelson, Martha I., and Edward C. Holmes. 2007. "The Evolution of Epidemic Influenza." Nature Reviews Genetics 8 (3): 196-205.

Nelson, Steven G. 2008. "Court and Religious Music: Gagaku and Shōmyō [Ch.2: History, Ch.3: Music].” In The Ashgate Research Companion to Japanese Music, edited by Alison McQueen Tokita and David W. Hughes, 35-76. Farnham, Surrey, UK: Ashgate.

Nettl, Bruno. 2006. "Response to Victor Grauer: On the Concept of Evolution in the History of Ethnomusicology." The World of Music 48 (2): 59-72.

- 2015. The Study of Ethnomusicology: Thirty-Three Discussions. 3rd ed. Champaign: University of Illinois Press.

Opie, Christopher, Susanne Shultz, Quentin D. Atkinson, Thomas Currie, and Ruth Mace. 2014. "Phylogenetic Reconstruction of Bantu Kinship Challenges Main Sequence Theory of Human Social Evolution." Proceedings of the National Academy of Sciences of the United States of America.

Pagel, Mark. 2009. "Human Language as a Culturally Transmitted Replicator." Nature Reviews Genetics 10 (6): 405-15.

—. 2016. "Darwinian Perspectives on the Evolution of Human Languages." Psychonomic Bulletin \& Review. doi:10.3758/s13423-016-1072-z.

Pagel, Mark, Quentin D Atkinson, and Andrew Meade. 2007. "Frequency of Word-Use Predicts Rates of Lexical Evolution throughout Indo-European History." Nature 449 (7163): 717-20.

Pamjav, Horolma, Zoltán Juhász, Andrea Zalán, Endre Németh, and Bayarlkhagva Damdin. 2012. "A Comparative Phylogenetic Study of Genetics and Folk Music." 
Molecular Genetics and Genomics 287 (4): 337-49.

Pareles, Jon. 2002. “Alan Lomax, Who Raised Voice Of Folk Music in U.S., Dies at 87." The New York Times. http://www.nytimes.com/2002/07/20/arts/alan-lomax-who-raised-voice-of-folk-m usic-in-us-dies-at-87.html.

Patel, Aniruddh D. 2008. Music, Language and the Brain. Oxford: Oxford University Press.

Pettan, Svanibor, and Jeff Todd Titon, eds. 2015. The Oxford Handbook of Applied Ethnomusicology. Oxford: Oxford University Press.

Picken, Laurence Ernest Rowland, R. F. Wolpert, and Noël J. Nickson, eds. 1981-2000. Music from the Tang Court [7 Volumes]. London: Oxford/Cambridge University Press.

R Core Team. 2015. "R: A Language and Environment for Statistical Computing." Vienna: R Foundation for Statistical Computing. https://www.r-project.org/.

Rahaim, Matthew. 2006. "What Else Do We Say When We Say 'Music Evolves?"” The World of Music 48 (3): 29-41.

Ravignani, Andrea, Tania Delgado, and Simon Kirby. 2016. "Musical Evolution in the Lab Exhibits Rhythmic Universals." Nature Human Behaviour 1 (7): 1-7. doi:10.1038/s41562-016-0007.

Rehding, Alexander. 2000. "The Quest for the Origins of Music in Germany circa 1900." Journal of the American Musicological Society 53 (2): 345-85.

Rice, Timothy. 2010. "Disciplining Ethnomusicology: A Call for a New Approach." Ethnomusicology 54 (2): 318-25.

Richerson, Peter J., and Robert Boyd. 2005. Not by Genes Alone: How Culture Transformed Human Evolution. Chicago: University of Chicago Press.

Robine, Matthias, Pierre Hanna, Pascal Ferraro, and Julien Allali. 2007. “Adaptation of String Matching Algorithms for Identificaton of near-Duplicate Music Documents." Workshop on Plagiarism Analysis, Authorship Identification, and Near-Duplicate Detection (PAN07): 37-43.

Rogers, Deborah S., and Paul R. Ehrlich. 2008. "Natural Selection and Cultural Rates 
of Change." Proceedings of the National Academy of Sciences of the United States of America 105 (9): 3416-20.

Rzeszutek, Tom, Patrick E. Savage, and Steven Brown. 2012. "The Structure of Cross-Cultural Musical Diversity." Proceedings of the Royal Society B: Biological Sciences 279 (1733): 1606-12.

Sachs, Curt. 1943. The Rise of Music in the Ancient World: East and West. New York: Norton.

Savage, Patrick E. 2017. 音楽の文化的進化を測るーーブリティッシュ・アメリ カンと日本の民謡・ポップス・古典音楽の事例を通して——[Measuring the cultural evolution of music: With case studies of British-American and Japanese folk, art, and popular music] [PhD dissertation, Tokyo University of the Arts]. http://tinyurl.com/SavagePhD

Savage, P. E., Chiba, G., Currie, T. E., Suzuki, H., \& Atkinson, Q. D. (2020). Sequence alignment of folk song melodies reveals cross-cultural mechanisms of musical evolution. PsyArXiv Preprint. https://doi.org/10.31234/osf.io/5rj6y

Savage, P. E. (2019). Cultural evolution of music. Palgrave Communications, 5(16), 112. https://doi.org/10.1057/s41599-019-0221-1

Savage, P. E. (2018). Alan Lomax's Cantometrics Project: A comprehensive review. Music \& Science, 1, 1-19. https://doi.org/10.1177/2059204318786084

Savage, P. E. (2019). Universals. In J. L. Sturman (Ed.), SAGE International Encyclopedia of Music and Culture (pp. 2282-2285). SAGE Publications. https://doi.org/10.4135/9781483317731.n759

Savage, Patrick E. 2011. "Musical Evolution and Human Migration: Classification, Quantification and Application.” MSc thesis, McMaster University.

Savage, Patrick E., and Quentin D. Atkinson. 2015. "Automatic Tune Family Identification by Musical Sequence Alignment." In Proceedings of the 16th International Conference on Music Information Retrieval (ISMIR), 162-68. 
Savage, Patrick E., and Steven Brown. 2013. "Toward a New Comparative Musicology." Analytical Approaches to World Music 2 (2): 148-97.

Savage, Patrick E., and Steven Brown. 2014a. "Mapping Music: Cluster Analysis of Song-Type Frequencies within and between Cultures.” Ethnomusicology 58 (1): $133-55$.

Savage, Patrick E., and Steven Brown. 2014b. "Pour Une Nouvelle Musicologie Comparée: Cinq Champs de Recherche, Cinq Débats Essentiels [Toward a New Comparative Musicology: Five Key Areas and Debates]." Anthropologie et Sociétés 38 (1): 193-216.

Savage, Patrick E., Steven Brown, Emi Sakai, and Thomas E. Currie. 2015. "Statistical Universals Reveal the Structures and Functions of Human Music." Proceedings of the National Academy of Sciences of the United States of America 112 (29): 898792.

Savage, Patrick E., Hiromi Matsumae, Hiroki Oota, Mark Stoneking, Thomas E. Currie, Atsushi Tajima, Matt Gillan, and Steven Brown. 2015. "How 'Circumpolar' Is Ainu Music? Musical and Genetic Perspectives on the History of the Japanese Archipelago.” Ethnomusicology Forum 24 (3): 443-67.

Savage, Patrick E., Emily Merritt, Tom Rzeszutek, and Steven Brown. 2012. "CantoCore: A New Cross-Cultural Song Classification Scheme." Analytical Approaches to World Music 2 (1): 87-137.

Savage, Patrick E., Adam T. Tierney, and Aniruddh D. Patel. 2017. "Global Music Recordings Support the Motor Constraint Hypothesis for Human and Avian Song Contour." Music Perception 34 (3): 327-34.

Sayers, Ken, Mary Ann Raghanti, and C. Owen Lovejoy. 2012. "Human Evolution and the Chimpanzee Referential Doctrine." Annual Review of Anthropology 41 (1): 119-38.

Seeger, Anthony. 1992. "Ethnomusicology and Music Law.” Ethnomusicology 36 (3): 345-59.

Seeger, Charles, ed. 1966. Versions and Variants of the Tunes of Barbara Allen [1 Casette]. Washington, DC: Archive of American Folk Song, Library of Congress. 
AFS L 54.

Serrà, Joan, Álvaro Corral, Marián Boguñá, Martín Haro, and Josep Ll. Arcos. 2012.

"Measuring the Evolution of Contemporary Western Popular Music." Scientific Reports 2 (521): 1-6.

Sharp, Cecil J. 1907. English Folk Song: Some Conclusions. London: Simpkin.

-1932. English Folk Songs from the Southern Appalachians. London: Oxford University Press.

Simon, Artur, and Ulrich Wegner, eds. 2000. "Music! The Berlin Phonogramm-Archiv (1900-2000) [4 CDs].” WERGO.

Smith, Temple F., and Michael S. Waterman. 1981. "Identification of Common Molecular Subsequences.” Journal of Molecular Biology 147: 195-97.

Spencer, Herbert. 1875. "Progress: Its Law and Cause." In Illustrations of Universal Progress: A Series of Discussions, edited by Herbert Spencer, 1-60. New York: D. Appleton \& Company.

Stock, Jonathan P. J. 2006a. "Clues from Our Present Peers? A Response to Victor Grauer." The World of Music 48 (2): 73-91.

World of Music 48 (2-3).

Stockwell, Craig A., Andrew P. Hendry, and Michael T. Kinnison. 2003. "Contemporary Evolution Meets Conservation Biology." Trends in Ecology \& Evolution 18 (2): 94-101.

Stone, Ruth. 2008. Theory for Ethnomusicology. Upper Saddle, NJ: Pearson/Prentice Hall.

Stumpf, Carl. 1911/2012. The Origins of Music. Translated by David Trippett. Oxford: Oxford University Press.

Szwed, John. 2010. Alan Lomax: The Man Who Recorded the World. New York: Viking.

Takezawa, Yasuko, Kazuto Kato, Hiroki Oota, Timothy Caulfield, Akihiro Fujimoto, Shunwa (Henry Stewart) Honda, Naoyuki Kamatani, et al. 2014. "Human Genetic Research, Race, Ethnicity and the Labeling of Populations: Recommendations 
Based on an Interdisciplinary Workshop in Japan.” BMC Medical Ethics 15 (33): 1-5. doi:10.1186/1472-6939-15-33.

Tehrani, Jamshid J., Mark Collard, and Stephen J. Shennan. 2010. “The Cophylogeny of Populations and Cultures: Reconstructing the Evolution of Iranian Tribal Craft Traditions Using Trees and Jungles." Philosophical Transactions of the Royal Society B: Biological Sciences 365 (1559): 3865-74.

Tëmkin, Ilya, and Niles Eldredge. 2007. "Phylogenetics and Material Cultural Evolution." Current Anthropology 48 (1): 146-54.

Terauchi, Naoko. 2011. "Surface and Deep Structure in the Tōgaku Ensemble of Japanese Court Music (Gagaku)." In Analytical and Cross-Cultural Studies in World Music, edited by Michael Tenzer and John Roeder, 19-55. New York: Oxford University Press.

Titon, Jeff Todd. 1992. "Music, the Public Interest, and the Practice of Ethnomusicology." Ethnomusicology 36 (3): 315-22.

Tokita, Alison McQueen, and David W. Hughes, eds. 2008. The Ashgate Research Companion to Japanese Music. Farnham, Surrey, UK: Ashgate.

Tomlinson, Gary. 2013. "Evolutionary Studies in the Humanities: The Case of Music." Critical Inquiry 39 (4): 647-75.

Toner, P.G. 2007. "The Gestation of Cross-Cultural Music Research and the Birth of Ethnomusicology." Humanities Research 14 (1): 85-110.

Toussaint, Godfried. 2013. The Geometry of Musical Rhythm: What Makes A "Good” Rhythm Good? Boca Raton, FL: CRC Press.

UNESCO. 2003. Convention for the Safeguarding of the Intangible Cultural Heritage. http://www.unesco.org/culture/ich/en/convention.

Urbano, Julián, Juan Lloréns, Jorge Morato, and Sonia Sánchez-cuadrado. 2011. "Melodic Similarity through Shape Similarity." In Exploring Music Contents: 7th International Symposium, CMMR 2010, 338-55.

van der Meer, Wim. 1975. "Cultural Evolution: A Case Study of Indian Music." Sangeet Natak: Journal of the Sangeet Natak Akademi 35: 49-65.

van Kranenburg, Peter, Jörg Garbers, Anja Volk, Frans Wiering, Louis Grijp, and 
Remco C. Veltkamp. 2007. "Towards Integration of MIR and Folk Song Research.” In Proceedings of the 8th International Conference on Music Information Retrieval (ISMIR), 505-8.

van Kranenburg, Peter, Anja Volk, and Frans Wiering. 2013. "A Comparison between Global and Local Features for Computational Classification of Folk Song Melodies." Journal of New Music Research 42 (1): 1-18.

van Kranenburg, Peter, Anja Volk, Frans Wiering, and Remco C. Veltkamp. 2009. “Musical Models for Folk-Song Melody Alignment." In Proceedings of the 10th International Society for Music Information Retrieval Conference (ISMIR), 50712.

van Wyhe, John. 2005. "The Descent of Words: Evolutionary Thinking 1780-1880." Endeavour 29 (3): 94-100.

Wallin, Nils L., Bjorn Merker, and Steven Brown, eds. 2000. The Origins of Music. Cambridge: MIT Press.

Watts, Joseph, Oliver Sheehan, Quentin D. Atkinson, Joseph Bulbulia, and Russell D. Gray. 2016. "Ritual Human Sacrifice Promoted and Sustained the Evolution of Stratified Societies." Nature 532: 228-31.

Whiten, Andrew, Robert A. Hinde, Christopher B. Stringer, and Kevin N. Laland. 2012. Culture Evolves. Oxford: Oxford University Press.

Windram, Heather F., Terence Charlston, and Christopher J. Howe. 2014. "A Phylogenetic Analysis of Orlando Gibbons's Prelude in G.” Early Music 42 (4): 515-28.

Wiora, Walter. 1953. Europäischer Volksegesang: Gemeinsame Formen in Charakteristischen Abwandlungen. Cologne: Arno Volk.

Zivic, Pablo H. Rodriguez, Favio Shifres, and Guillermo A. Cecchi. 2013. "Perceptual Basis of Evolving Western Musical Styles." Proceedings of the National Academy of Sciences of the United States of America 110 (24): 10034-38. 